\title{
ARISTÓTELES LENDO OLAVO DE CARVALHO: DE UMA RETÓRICA ERÍSTICA *
}

Aristotle reads Olavo de Carvalho: about eristic rhetoric

Cesar de Alencar **

Resumo: Este estudo pretende apresentar uma interpretação acerca da concepção de discurso que explica e justifica a atuação textual e midiática de Olavo de Carvalho, tendo como ponto de partida sua obra sobre a pretendida teoria dos quatro discursos em Aristóteles. A partir da demonstração de que não se trata de uma interpretação decididamente aristotélica, constatamos ser necessário considerá-la como uma reflexão programática de Carvalho sobre certo uso do discurso para fins políticos, que chamo de retórica erística, e cuja intenção se define pelo estabelecimento do saber e do livre debate de ideias como inescapáveis à lógica persuasiva do embate erístico, aquele em que o que conta é vencer o debate sem precisar ter razão. Essa intenção é confirmada pelo cotejo com as obras mais decisivas ao tipo de exercício de poder pretendido pelo autor, e que nos esclarecem sua satisfação em insuflar o impedimento do debate por via dupla: a de forjar, para seus leitores, uma impressão de que possuem a verdade que os situa acima das intelectualidades de todo tipo; e a de, por conta dessa impressão, atomizá-los na verborragia de sua opinião única. $O$ efeito pedagógico dessa retórica erística é imbuir seus alunos de uma missão política, claramente circunscrita ao ódio pelo comunismo e pela verdade enquanto nascida não do silêncio individual, mas do diálogo entre interessados pelo saber.

Palavras-chave: Discurso. Política. Aristóteles. Olavo de Carvalho.

Abstract: This paper suggests an interpretation of the conception of discourse that can explain and justify Olavo de Carvalho's textual and media performance. Its starting point is Carvalho's own work on the Theory of the Four Discourses,

\footnotetext{
* Artigo recebido em 05/05;2021 e aprovado para publicação em 19/09/2021.

** Escritor e Professor. Universidade Federal do Amapá - Colegiado de Filosofia.
} 
which he claims is Aristotle's. After demonstrating that it is decidedly not a valid interpretation of Aristotelian thought, we found necessary to consider Carvalho's work as a programmatic content of his own proposal on the use of discourse for political purposes, which we call eristic rhetoric. His intention is to show that knowledge and the free debate of ideas cannot escape the persuasive logic of eristic rhetoric, for which what counts is to win the debate, without needing to be right. Carvalho's intention is confirmed by the comparison with other works of his concerning the type of exercise of power that he clearly supports. Such a comparison clearly demonstrates his satisfaction in hindering the debate in two ways: by creating in his readers the impression they possess the truth, placing them above intellectuals of all kinds; and thereby leading them to adopt a single opinion, characterized by verbiage, that reduces them to mere atoms of the social body. The effect of this rhetoric of contention is to imbue his students with a political mission that fosters hatred of communism and of the truth. An authentic debate does not originate from the closure in oneself but from the dialogue between those interested in knowledge.

Keywords: Speech. Power. Aristotle. Olavo de Carvalho.

Erudição não ensina sabedoria.

Heráclito

\title{
Introdução
}

\begin{abstract}
$\longrightarrow$
ostuma-se descrever a ascensão política da nova direita ${ }^{1}$, em 2018, como devedora do que foi considerado o retorno do conservadorismo no Brasil. Mas não há propriamente retorno do que nunca foi embora, e mantendo a sociedade brasileira traços conservadores em sua história cultural e política ${ }^{2}$, seria mais adequado dizer que o alegado retorno deveu-se, antes de tudo, a uma atuação cultural que pensadores mais afinados com a perspectiva liberal, em economia, e com o imaginário religioso-cristão, em moralidade, alcançaram junto a veículos de massa,
\end{abstract}

\footnotetext{
${ }^{1} \mathrm{O}$ termo costuma ser empregado, genericamente, para dizer algo sobre a ascensão conservadora tal como ela se materializou na vitória de Jair Bolsonaro à Presidência da República em 2018, reunindo elementos de retórica do ódio e de guerra cultural analisados por diferentes estudos, dos quais citamos os de Manso (MANSO, Bruno P. A república das milícias: Dos esquadrões da morte à era Bolsonaro. São Paulo: Todavia, p. 230ss), de Mello (MELLO, Patrícia C. A máquina do ódio. São Paulo, Cia das Letras, 2020) e, principalmente, o de Rocha (ROCHA, João. Guerra Cultural e Retórica do ódio. Goiânia, Caminhos, 2021), por ser mais completo na caracterização do fenômeno.

${ }^{2}$ Sobre os traços do conservadorismo brasileiro e a dita ascensão do conservadorismo com ênfase na postura autoritária, ver SCHWARCZ, Lilia. Sobre o autoritarismo brasileiro. São Paulo, Cia das Letras, 2019. Ao contrário do que Carvalho costuma defender, o brasileiro em média se mostra mais afinado a posições políticas não conservadoras [https://valor.globo.com/ politica/coluna/pesquisa-sugere-baixa-adesao-de-brasileiros-a-teses-conservadoras-1.ghtml].
} 
potencializados por novas tecnologias e pela ampliação do acesso à internet. Aos que observam o significativo paralelo entre o surgimento dessas mídias digitais e a presença reacionária que ameaça o poder consolidado de instituições democráticas como a mídia tradicional, as universidades e o parlamento, a atuação pioneira e paradigmática de Olavo de Carvalho não pode ser desprezada, sobretudo se quisermos compreender o traço intelectual dessa escalada do ódio contra parcela significativa da população, constantemente rotulada de 'inimiga pública' - eufemismo para o sentido do termo comunista, utilizado em larga escala a partir da referência ao modo de Carvalho pensar a política ${ }^{3}$.

Mas de que modo de pensar se trata? A maioria dos críticos ao pensamento de Olavo de Carvalho raramente aventura-se a analisar mais do que um ou outro de seus posts em redes sociais, talvez uma entrevista ou um vídeo qualquer entre os que circulam pela internet; quando muito, passam rapidamente os olhos pelos artigos daquelas suas obras mais vendidas e conhecidas $^{4}$, nada conhecendo dos demais livros que reúnem aquilo que o autor chamaria sua filosofia. É preciso, porém, dar o devido crédito a um pensamento que pretende ser filosófico, que convida à esperada análise realizada por um trabalho intelectual sério e empenhado em diagnosticar a raiz dos últimos acontecimentos no cenário político brasileiro, trabalho que vem aos poucos surgindo com a envergadura merecida. É preciso, portanto,

\footnotetext{
${ }^{3}$ Qualquer um que conheça mais de perto a atividade intelectual de Carvalho, reconhece a dedicação persistente com que situa ideias adversárias como oriundas de uma política comunista de cunho hegemônico, que pretende dominar o cenário mundial, em franca ameaça ao legado ocidental. Uma amostra dessa sua descrição pode ser conferida em CARVALHO, Olavo de. A nova era e a revolução cultural. Fritjof Capra \& Antonio Gramsci. Campinas: Vide editorial, 2014 (1eded. 1994), obra a partir da qual viu-se também estimulada a utilização da expressão marxismo cultural no debate nacional, além do conhecido (nos meios olavianos) debate com o intelectual russo Alexandre Dugin, em que o comunismo é descrito como uma cultura propagada pelo projeto eurasiano de dominação das elites de Rússia e China (CARVALHO, Olavo de. Os EUA a Nova Ordem Mundial. Um debate entre Alexandre Dugin e Olavo de Carvalho Publicado no Brasil. Campinas, Vide editorial, 2012).

${ }^{4}$ Refiro-me aqui aos dois best-sellers CARVALHO, Olavo de. O imbecil coletivo. Rio de Janeiro, Record, 2019 (1를. 1996) e, sobretudo, CARVALHO, Olavo de. O mínimo que você precisa saber para não ser um idiota. Rio de Janeiro, Record, 2013. No primeiro, encontramos as principais teses e crenças de Olavo sintetizadas, com um estilo desenvolto e sedutor, em seu confronto com importantes figuras do cenário intelectual brasileiro. No segundo, foi realizada uma reunião de artigos de Olavo por Felipe Moura Brasil, em meio à escalada do que se rotula nova direita, com o objetivo declarado de tornar essas teses e crenças olavianas um padrão de racionalidade para o homem médio tupiniquim, um antídoto para "a canalhice [que] é a ciência mais avançada do mundo atual". Daí até terminar no slogan "Olavo tem razão" foi um pulo. Sobre as ramificações das ideias e crenças de Carvalho a partir dessa frase-emblema, ver Rocha (ob. cit., p. 49ss). Ouçamos também a indicação de HUSSNE, Arthur. “Olavismo e bolsonarismo". Rosa, I, março de 2020 [disponível em https://revistarosa.com/1/olavismo-e-bolsonarismo]: "Neste momento, fica evidente que as teorias de Olavo haviam ganhado não apenas repercussão midiática, mas base popular: todo esse discurso, que parecia obscuro para muitos, circulou incessantemente por intelectuais secundários, sobretudo após 2013. Foi a partir desse momento que começaram a pipocar pelas redes a hashtag \#olavotemrazão".
} 
compreender o alcance político da influência intelectual de Carvalho ${ }^{5}$. O fenômeno que ocupou as ruas do país a partir de junho de 2013, e que desaguou na revolta contra o resultado das eleições de 2014 e no processo de impeachment da presidente reeleita em 2015, vez ou outra chegou a repercutir a frase tornada lapidar dessa influência olaviana: "Olavo tem razão" era o grito dos que faziam questão de levantar seu exemplar de $O$ mínimo que você precisa saber para não ser um idiota (2013) como, talvez, a garantia de sua entrada na esfera da alta cultura ou, ao menos, da saída da cultura dos idiotas - assumindo, ironicamente, uma forma de idiotia coletiva, cuja máxima esteve em identificar a encarnação da racionalidade na voz beligerante do autor do livro.

É preciso, portanto, não desprezar esse sintoma de decadência cultural, repercutido na substituição da razão pelo personalismo daquele que supostamente a encarna. Não podemos, também, desprezar a tarefa de avaliação racional desse tipo de influência política de um discurso. Sem postularmos, de início, uma negativa sobre o pensamento de Carvalho ser ou não filosófico, assumiremos sua própria perspectiva, enquanto determinada por aquilo que ele define como "a unidade do conhecimento na unidade da consciência e vice-versa" ${ }^{\prime}$ - a fim de esclarecer, desse modo, sua atuação política e influência cultural pelos princípios do que ele considera o filosofema, sem o qual não existiria filósofo: quer dizer, aquele "sistema ideal de intuições e pensamentos que se oculta por trás dos textos", e que dá unidade às atitudes pessoais com as quais o filósofo encarna suas ideias, como sua "intepretação vivente ante as situações da existência"7. Iremos, no entanto, atrás dos textos. O caminho, desse modo, está em nos valermos de sua maneira de pensar para unificarmos as atividades que lhe dão a interpretação existencial, do mesmo modo que tais atividades são o que permitem ao estudioso diagnosticar uma obra avessa à sistematicidade. Creio ser possível constatar, ao final, que a posição discursiva de Carvalho o situa como um escritor cuja atuação intelectual objetiva dar vazão a um conjunto de expressões simbólicas capazes de gerar, como por reação

\footnotetext{
5 "Compreender o alcance do fenômeno é o primeiro passo para superá-lo" (ROCHA, ob. cit., p. 66). Essa influência já foi largamente confirmada, desde afirmações de importantes intelectuais, como Ruy Fausto ("a figura principal desse esquema, pelo menos no plano ideológico, foi e é Olavo de Carvalho"), até declarações dos filhos de Bolsonaro, como o Eduardo ("uma inspiração, e sem ele Jair Bolsonaro não existiria"). Há aqui, contudo, uma dificuldade sobre a qual não poderemos nos ater no espaço deste artigo, que diz respeito aos processos de guerra híbrida, estudados por LEIRNER, Piero. O Brasil no espectro de uma guerra híbrida. São Paulo, Alameda, 2020, e que indicam uma proximidade entre as ideias de Carvalho e os interesses políticos de militares do alto escalão brasileiro - proximidade que, para explicar os efeitos de causalidade, qualquer que fosse o seu vetor, exigiria um estudo específico.

${ }^{6}$ Cf. CARVALHO, Olavo de. A dialética simbólica. Ensaios reunidos. Campinas, Vide Editorial, 2015, p. 6 (1 ${ }^{\text {eed. } 2007) . ~}$

${ }^{7}$ Idem p. 57 ss.
} 
a estímulos, o estorvo do debate público e a postura de eliminação do adversário político ${ }^{8}$.

Para isso, o presente estudo pauta-se numa análise daquilo que considero ser o centro da compreensão olaviana sobre o discurso e os modos pelos quais se pode utilizá-lo, a fim de reduzir o outro ao silêncio: a chamada teoria dos quatro discursos, a confecção intelectual que permeia a obra de Carvalho e que foi por ele mesmo condensada no estudo que parece tê-la originado, qual seja, Aristóteles em nova perspectiva (1996). Pretendo mostrar que essa nova perspectiva oferecida pelo escritor brasileiro denuncia sua estruturação do discurso por um interesse político e, sobretudo, erístico, não tendo muito a ver com o que em Aristóteles compreendemos ser sua filosofia. Essa confecção intelectual olaviana nos esclarece, de modo evidente a partir de um cotejo possível com obras decisivas ao tipo de exercício de poder pretendido pelo autor, a unidade de consciência por trás da variedade aparentemente desconexa de seus meios de atuação. Em outras palavras, é possível encontrar, na maneira pela qual Carvalho lê Aristóteles, a interpretação discursiva que Carvalho, e não Aristóteles, põe em prática na sua atuação pública. Aos olhos do Estagirita, em contrapartida, a atuação discursiva de Carvalho poderia ser descrita como uma retórica erística: a confluência da prática de uma dialética erística com os recursos persuasivos da retórica, capaz de impedir o debate de ideias pela simbólica do silêncio e do seu efeito no ódio ao outro, sustentado pelo anseio de mostrar, acima de tudo, como vencer um debate sem precisar ter razão9.

${ }^{8} \mathrm{O}$ que chamo aqui de conjunto de expressões simbólicas guarda relativa afinidade com o conceito de sistema de crenças Olavo de Carvalho, muito apropriadamente descrito por Rocha (ob. cit.), mas do qual me afasto (mais para poder complementá-lo do que para descartá-lo) a fim de destacar a matriz filosófica que fundamenta o uso retórico dos discursos, tal como Carvalho a sistematizou em CARVALHO, Olavo de. Aristóteles em Nova perspectiva. São Paulo, É Realizações, 1996, e que me parece central para entendermos o deslocamento da consciência do leitor, silenciado pela razão de Carvalho, do necessário debate de ideias para uma postura de aniquilação do outro - ou, em termos aristotélicos, a redução da dialética à erística, que se vale dos variados modos de discurso estruturados com finalidade persuasiva. Essa retórica erística, como chamarei, repercute certas expressões simbólicas enquanto matriz da missão mística a que ele pretende destinar seus alunos, e que ficará mais clara na última seção deste artigo. O que Rocha chamou sistema de crenças Olavo de Carvalho me parece, antes de tudo, condicionado pela retórica erística, sendo esta mais fundamental que as próprias expressões simbólicas que ela veicula.

${ }^{9}$ Este foi o título endossado por Carvalho para uma tradução que fez sobre as lições erísticas de SCHOPENHAUER, Arthur. Como vencer um debate sem precisar ter razão. Dialética Erística. Introdução, comentários e notas de Olavo de Carvalho. São Paulo, Topbooks, 1997. Se devidamente observada, ao lado das principais obras lançadas por ele em um curto período de tempo, a começar pela trilogia cultural (A nova era e a Revolução Cultural, O jardim das Aflições e $O$ imbecil Coletivo) e seguida pela obra sobre Aristóteles aqui analisada, essa despretensiosa tradução se mostra, na verdade, como uma realização prática das intenções pelas quais deveríamos ler as obras precedentes. Indicaremos, na última seção deste estudo, uma aproximação entre essa tradução e a obra sobre Aristóteles, em vista de melhor delimitarmos essa leitura de uma retórica erística em Carvalho. 


\section{Carvalho lendo Aristóteles}

\section{a. Proposta de inversão interpretativa: a lógica dos quatro discursos}

A proposta do livro de Olavo sobre Aristóteles está em, segundo suas palavras, poder compreender Aristóteles - o que significa dizer, "captar a unidade do pensamento de um homem desde suas próprias intenções e valores, em vez de julgá-lo de fora; ato que implica respeitar cuidadosamente o inexpresso e o subentendido, em vez de sufocá-lo na idolatria do 'texto' coisificado, túmulo do pensamento" ${ }^{10}$. Seria preciso, desse modo, seguir as pistas do que Aristóteles não disse para ser possível reconstruir a suposta unidade em torno da concepção aristotélica do discurso. É de suma importância que nos atentemos para esse tipo de inversão interpretativa: o esforço de Carvalho está em ter acesso às intenções do autor sem se valer, é preciso deixar claro, da única forma legítima de acesso pela qual podemos alcançá-la, ou seja, a obra realizada pelo autor a ser interpretado. Em vez, portanto, de julgá-lo de fora, a partir de uma ditadura do texto ${ }^{11}$, seria preciso adentrar a mente do autor pelo que ele não disse, seguindo, diz Carvalho, "desde suas próprias intenções e valores" - de um modo, ao que tudo indica, distinto do tipo de interpretação esotérica que fora tantas vezes defendida pelo filósofo Leo Strauss, e que recorria às linhas do texto para, a partir delas, captar as entrelinhas ${ }^{12}$. A questão hermenêutica decisiva que se coloca está em saber, afinal, como ter acesso às intenções e aos valores de um autor, como adentrar a mente do outro sem se valer, para isso, da primazia (bem diferente de idolatria) do texto?

O que constatamos, a partir do primeiro apontamento, é o estabelecimento de um princípio hermenêutico no mínimo duvidoso. Ao contrário de Schleiermacher e Dilthey, os pais da hermenêutica que estabeleceram princípios para uma compreensão derivada do texto, Carvalho inverte a lógica hermenêutica a fim de situar sua visão aristotélica desde fora do texto. Isso tende a projetar sobre a obra de um autor elementos por vezes estranhos a ela, já que a obra textual deixa de ser a referência última ${ }^{13}$. Esse tipo

\footnotetext{
${ }^{10}$ CARVALHO, Olavo de. Aristóteles em nova perspectiva, ob. cit. p. 27

${ }^{11}$ Contra a suposta ditadura do texto, Carvalho apresentou um programa filosófico como contraposto, segundo ele, à prática gueroultiana de idolatria textual realizada pela filosofia uspiana em CARVALHO, Olavo de. A filosofia e seu inverso. Campinas, Vide editorial, 2012. ${ }^{12}$ Sobre a leitura nas entrelinhas e a perspectiva da escrita esotérica, ver STRAUSS, Leo. Persecution and the Art of Writing. New York, The University of Chicago Press, 1988.

${ }^{13} \mathrm{O}$ método hermenêutico, ao se firmar como técnica de interpretação, desenvolve-se sob a referência textual, de modo que apenas por extensão de significado poderíamos dizer, como o faz o próprio Schleiermacher, que é preciso ser um hermeneuta mesmo em conversas do cotidiano (SCHLEIERMACHER, Friedrich. Hermenêutica: arte e técnica da interpretação. Petrópolis, Vozes, 2010). E se, em Dilthey, a vida humana é favorecida pela técnica de
} 
de implicação psicológica, chamemos assim, projetou quatro dimensões que supostamente seriam fundamentais ao uso do lógos em Aristóteles, revelando uma certa orientação cardinal denominada por Carvalho de teoria dos quatro discursos: "o discurso humano é uma potência única, que se atualiza de quatro maneiras diversas: a poética, a retórica, a dialética e a analítica (lógica)"14. Por serem essas quatro maneiras diversas, na verdade, quatro ciências do discurso, ao se estudar as variantes da potência única, não se deveria senão constatar, ao final, a razão da unidade do objeto estudado, ou seja, o lógos, "sob pena de falharem à regra aristotélica das divisões"15. As quatro atualizações devem ser compreendidas em função da potencialidade única.

Se as divisões aristotélicas do saber estão aqui postas como norte, isso é ao menos um alívio. A questão que se impõe, no entanto, é saber se os ditos quatro discursos são ciências do discurso; mais ainda, se elas, em conjunto, referem-se à sua unidade. Por essa formulação do problema, o conhecedor da filosofia aristotélica já percebe a confusão se avizinhar. Antes de tudo, não há, em Aristóteles, ciência senão do universal, e alguém poderia argumentar que o lógos, ao universalizar o singular a partir de seus termos gerais ${ }^{16}$, configura ele mesmo o território que dá a unidade da ciência - mas de um modo a não mais permitir que se consiga estabelecer um critério de distinção das maneiras diversas de sua manifestação: ou seja, sob esse ponto de vista, o discurso é a raiz da ciência, e a distinção entre o discurso analítico, que Carvalho aloca como especificamente científico porque verdadeiro, e o poético, seu antípoda, seria tão-somente uma diferença de grau, não em termos cognitivos, mas em vista do tipo de credibilidade a que se destinam. Em outras palavras, a unidade de ciência dos vários modos de atualizar o lógos teria, para Aristóteles segundo Carvalho, a intenção (não declarada pelo texto, "túmulo do pensamento") de obter diferentes níveis de credibilidade junto ao seu ouvinte - de modo que a teoria dos quatro discursos acaba por organizar as obras aristotélicas sob o enfoque não do conhecimento, mas da persuasão.

interpretação, na medida em que o indivíduo só conhece a si mesmo pelo contraste com a manifestação da consciência alheia, a compreensão almejada não pode se ausentar do texto, onde de fato encontra a objetividade fixa da experiência vivencial que torna possível a interpretação enquanto arte (DILTHEY, Wilhelm. "O surgimento da hermenêutica". Tradução Eduardo Gross [1ed. 1900]. Numen: revista de estudos e pesquisa da religião, Juiz de Fora, v. 1. n. 1, p. 11-32, 1999.

${ }^{14}$ Ibidem, p. 30.

${ }^{15}$ Ibidem, p. 31.

${ }^{16}$ O próprio Carvalho denuncia a tentativa de caracterizarem sua obra com um argumento semelhante: "a mente humana está mal equipada para perceber as singularidades como tais: ou as expele logo do círculo de atenção, para evitar o incômodo de adaptar-se a uma forma desconhecida, ou as apreende somente pelas analogias parciais e de superfície que permitem assimilá-las erroneamente a alguma classe de objetos conhecidos" (CARVALHO, Olavo de. O imbecil coletivo, ob. cit. p. 28). 
A maneira como Carvalho elabora sua aproximação com a obra aristotélica é deveras inquietante, e de certa forma tende a confirmar nossa suspeita. $\mathrm{O}$ escritor chega a se perguntar se de fato Aristóteles pensou uma unidade dos discursos ou não, e se ele teve razão em pensar assim, no caso de tê-la realmente pensado. $\mathrm{O}$ argumento estabelecido, porém, pretende ser ao mesmo tempo uma resposta à sua própria pergunta e uma justificativa da necessidade do seu método: por se tratar da interpretação do pensamento de um filósofo distante de nós muitos séculos, diz Carvalho, a compreensão dependeria da possibilidade de esclarecermos aquilo que Aristóteles precisava saber para dizer o que disse. Duas coisas aqui se deduzem: (a) pode-se considerar, desse modo, o que passamos a saber e a fazer a partir de uma obra como se isso pertencesse ao próprio autor, às suas intenções e valores, tal como se poderia dizer de Platão que sua intenção era produzir regimes totalitários, ou a de Einstein, o surgimento da bomba atômica; (b) inverte-se mais uma vez outro preceito hermenêutico (o da possibilidade de conhecermos o autor melhor do que ele mesmo pôde fazê-lo), mostrando que uma suposta compreensão a partir daquilo que o autor precisava saber para dizer o que disse confere ao próprio autor a intencionalidade pelo que ele não deixou explícito, o que acaba por invalidar o preceito, já que o autor estaria plenamente consciente de todas as determinantes contextuais e prospectivas de sua obra. Para Carvalho, os usos aristotélicos do discurso reverberam um saber latente sobre a unidade do lógos, pressuposta e não declarada pelo Estagirita - e talvez devêssemos dizer, invertendo a proposta invertida de Carvalho, que seu estudo de Aristóteles é, sobretudo, a objetividade fixa que nos permite interpretar aristotelicamente as intenções e os valores de Olavo. Mas se invertê-lo é retornar ao exercício fundamental da interpretação, devemos nos aproximar do texto olaviano para então compreendê-lo melhor do que ele mesmo pôde fazê-lo.

\section{b. A confusão dos quatro discursos: o argumento histórico acerca do Órganon}

Há um argumento histórico que complementa o recurso da interpretação olaviana. Não se poderia assegurar, diz ele, que a organização posterior dos escritos de um filósofo correspondesse à organização que o filósofo de fato dera ao saber, em geral, e ao seu próprio, em particular. A divisão da obra aristotélica, legada por Andrônico de Rodes no século I a.C., assentar-se-ia formalmente sobre as quatro dimensões do saber que ele identificava no Estagirita (Introdutórios, Teoréticos, Práticos e Técnicos), divisão que, afirma Carvalho, acabou por influenciar a separação decisiva da Poética e da Retórica, postas como técnicas, do restante do Órganon, exposto como introdutório - o que provoca, para Carvalho, a falsa impressão de que aquelas duas não estejam integradas ao corpus de obras lógicas, sobre o 
lógos, como deveriam estar, aristotelicamente falando. Face a esta imprecisão de Andrônico, perdeu-se o traço orgânico da concepção aristotélica acerca do discurso - e a proposta de Carvalho, que possuiu, em seu entender, apenas dois antecedentes ao longo da tradição de estudos aristotélicos ${ }^{17}$, pretende fazer retornar a Poética e a Retórica para o âmbito do Órganon, que lhes seria mais adequado ${ }^{18}$.

É preciso esmiuçar com vagar esse tipo de argumento, a fim de destacar os lances no jogo de palavras e no manejo das informações, ou da falta delas, oferecidos por Olavo. Um primeiro ponto está em que, tendo Andrônico de Rodes supostamente se baseado na divisão do conhecimento em Aristóteles, não faria sentido dizer, como diz Olavo, que a organização posterior, oferecida pelo alexandrino, estivesse em dissintonia com a organização pensada pelo próprio Estagirita. Se para Carvalho o papel da compreensão está em captar o que outro precisa saber para ter dito o que disse, Andrônico se apresenta perfeitamente legitimado em sua ordenação da obra aristotélica valendo-se do tipo de classificação do conhecimento feita pelo próprio filósofo, não enquanto uma interpretação vinda de fora do texto, mas a partir das próprias obras ${ }^{19}$. Em outras palavras, assumido o critério aristotélico do conhecimento, a organização da sua obra não pode se mostrar mais adequada que a de Andrônico, no interior da qual não parece fazer sentido alocar a Poética e a Retórica como obras introdutórias.

A questão se complica quando averiguamos os fatos em torno ao legado do Corpus Aristotelicum. Carvalho diz terem se perdido as obras de Aristóteles, até seu reaparecimento no século I a.C. a partir da edição feita por Andrônico, paradigmática até hoje ${ }^{20}$. Ocorre que as obras aristotélicas que haviam se perdido eram as chamadas esotéricas, que se compunham por anotações das aulas ministradas no Liceu; as demais, ou seja, seus diálogos e escritos exotéricos, continuaram não só conhecidos, como tinham sido responsáveis então por moldar a visão sobre a filosofia do Estagirita

\footnotetext{
${ }^{17}$ Os dois casos seriam os de Avicena e Tomás de Aquino, este muito provavelmente se baseando na perspectiva daquele (CARVALHO, Olavo de. Aristóteles em nova perspectiva, ob. cit. p. 26, n. 8). Veremos que, na verdade, esse tipo de proposta tinha sido comum aos neoplatônicos, em sua tentativa de organizar as obras de Aristóteles, seguindo princípios, no entanto, relacionados à ontologia neoplatônica, em debate com o estoicismo - debate que haveria de influenciar as concepções árabe e cristã.

${ }^{18}$ Ibidem, p. 32-33.

${ }^{19}$ Pois é de Aristóteles a distinção em três âmbitos de conhecimento (theoretiké, praktiké, poiétiké; cf. Tópicos, VI, 6, 145a15; Metafísica, VI, 1, 1025b25; Ética a Nicômaco, VI, 2, 1139a28), ao passo que a noção de órganon, relacionada à lógica, é criação de Andrônico, derivada das considerações de método apresentadas em Tópicos, I, 100a25-101a24. As indicações e os argumentos acerca dessa concepção androniciana para organizar a obra aristotélica foram analisados, de maneira exaustiva, por MESQUITA, Pedro. Introdução geral. As obras completas de Aristóteles. Lisboa, INCM, 2005, p. 245ss. Dado o espaço curto para exposição, faremos referência aqui apenas aos pontos conclusivos principais.

${ }^{20}$ Ibidem, p. 32.
} 
até o retorno à cena dos papiros perdidos. Estes foram levados por um discípulo do Liceu, sucessor legitimo de Teofrasto segundo testamento ${ }^{21}$, e só foram recuperados devido à eventualidade de terem eles retornado para Atenas em razão de trocas comerciais com Roma, por volta do século I a.C. A descoberta desse material perdido promoveu intensa divulgação da filosofia aristotélica, desencadeando exercícios de comentários ao texto de Aristóteles realizados por diversos peripatéticos da época, entre os quais Andrônico de Rodes, que obteve maior sucesso ao propor, num curso, seu "Aristóteles Completo" 22. Tal sucesso, explica Rossetti, deveu-se à dedicação com a qual Andrônico valorizou e acentuou, em sua apresentação, as opções de classificação que tinham sido indicadas e esboçadas pelo próprio Aristóteles em seus textos ${ }^{23}$.

Um segundo ponto está em que, para Carvalho, aquela "casualidade editorial" de Andrônico teria acumulado, para a história das ideias, um preconceito face às "ciências" da poética e da retórica, ao serem ambas alocadas sob o âmbito da técnica, e não da lógica: "como ciências do discurso, a Poética e a Retórica fazem parte do Organon, conjunto das obras lógicas ou introdutórias, e não são portanto nem teoréticas nem práticas nem técnicas. Este é o núcleo da interpretação que defendo" ${ }^{24}$. Dada a centralidade da tese sobre a composição do Órganon, precisamos prolongar nosso excurso, a ver com precisão o conjunto de equívocos reunidos por Carvalho em sua pretendida nova perspectiva.

De fato, foi criação do gênio sistemático androniciano o estabelecimento do Órganon, composto de obras então separadas, mas cuja temática ele entendera complementar, porque seu propósito foi organizar as obras dispersas em grandes tratados (eis pragmateíais, no dizer de Profírio), isto é, em unidades bibliográficas abrangentes que abrigavam estudos similares a fim de dispô-los de modo a reproduzir princípios aristotélicos, como ocorreu também no caso de Parva Naturalia. Um outro ponto importante é levantado com referência à forma de classificar as obras de Aristóteles. As listas de classificação que nos chegaram, ao que parece, repercutem uma estrutura comum, cuja inspiração aristotélica vê-se, sobretudo, na tríade do conhecimento que separa as obras segundo seus fins. Mas encontramos

\footnotetext{
${ }^{21}$ Trata-se de Neleu de Cépsis, designado em testamento por Teofrasto como escolarca que lhe deveria suceder. Contudo, as manobras de Estratão de Lampsaco para assumir o Liceu levaram ao exílio Neleu, que decidiu retirar-se para sua cidade de posse dos papiros esotéricos de Aristóteles e de Teofrasto. Foram esses que, dois séculos depois, seriam encontrados pelos romanos em Atenas (cf. ROSSETTI, Lívio. Introdução à Filosofia Antiga. Tradução de Élcio Viçosa Filho. São Paulo, Paulus, 2006, p. 165).

${ }^{22}$ Os dados sobre essa descoberta dos papiros do Corpus Aristotelicum, contada por Estrabão, encontram-se em Mesquita ( $o b$. cit, p. 209ss), que os analisou em detalhes para situar sua contribuição como testemunho histórico inclusive para os processos de classificação da obra aristotélica; ver também Rossetti (ob. cit, p. 165ss).

${ }^{23}$ Cf. ROSSETTI (ob. cit, p. 167).

${ }^{24}$ Ibidem, p. 38.
} 
também o quarto âmbito, lógico - em relação ao qual a tese de Carvalho pretende se sustentar. O cotejamento das três listas que nos chegaram ${ }^{25}$ indica, pela ausência dos escritos esotéricos nos catálogos mais antigos, feitos por Diógenes Laércio e por um Anônimo, e pela presença deles na lista de Ptolemeu, que lhes é tardia e evidentemente influenciada pela organização de Andrônico, haver não apenas essa diferença de conteúdo, como também uma diferença de aspecto formal, que diz respeito à iniciativa androniciana de, sobretudo, reunir certas obras dispersas em tratados temáticos (pragmateía), projeto do qual o Órganon é não só o primeiro mas o único devidamente terminado ${ }^{26}$.

Caberia, desse modo, averiguar se a proposta de Andrônico, que aponta um progresso significativo na reunião e organização das obras aristotélicas tal como a temos hoje, mantém a mesma inspiração das listas mais antigas, qual seja, aquela relativa à concepção aristotélica de conhecimento. E o caso do Órganon é paradigmático. As obras que hoje compõem esse tratado lógico de fato aparecem isoladamente nas listas mais antigas, ainda que com títulos diferentes. Essa presença ratifica a importância para Aristóteles do âmbito lógico como um campo de investigação originalmente criado por ele próprio ${ }^{27}$. O que Andrônico se propôs a fazer foi simplesmente reunir os estudos dispersos a partir de uma ordenação já prefigurada pelo texto aristotélico, ao menos naquilo que o texto indica como uma vinculação necessária entre a silogística de Tópicos e a dos Analíticos, ao final acrescida da de Refutações Sofísticas, acerca dos quatro tipos de argumentos fundamentais ao Estagirita ${ }^{28}$. Coube a Andrônico apenas situar Categorias

${ }^{25}$ Há três listas das obras de Aristóteles: o catálogo de Diógenes Laércio, o de um Anônimo e o de Ptolemeu, sendo este último a fonte comum das versões árabes. O cotejo entre elas, segundo Mesquita, indicaria haver sido, as duas mais antigas, referidas a alguma outra anterior cuja autoria geralmente se atribuía a Hermipo, até que o estudo de Moraux (MORAUX, Paul. Les listes anciennes de ouvrages d' Aristote. Louvain, Éditions Universitaires, 1951), indicou Aríston como seu provável autor, com base numa familiaridade evidente do autor com a obra aristotélica, própria a um peripatético. A lista mais antiga é muito provavelmente do século III a.C. Ela denuncia, no entanto, a falta daquelas obras ditas esotéricas, que só aparecerão na lista de Ptolemeu e num apêndice a do Anônimo, então posteriores, por esse motivo, à descoberta dos trabalhos perdidos do Estagirita, sendo, portanto, posteriores à organização realizada por Andrônico. O caso da lista de Ptolemeu é o mais decisivo, por conter uma apresentação quase completa do corpus, de modo a evidenciar a contribuição de Andrônico ao organizá-lo numa "ordem temática inspirada directamente nos princípios da filosofia aristotélica" (Mesquita, ob. cit, p. 238).

${ }^{26}$ A indicação é de Mesquita (ob. cit., p. 247), baseando-se em alguns testemunhos independentes. Fato é que, mesmo em função dessas pretensas diferenças entre as listas antigas e tardias, a estrutura do corpus não sofreu nenhuma alteração substantiva, em ambos os casos se mantendo, perceptível, a ordenação das obras em função dos saberes segundo os ensinamentos do Estagirita (Mesquita, ob. cit, p. 261).

${ }^{27}$ Ver a própria indicação de Aristóteles ao final de Refutações Sofísticas, 34, 183b15-184b8, e que parece dizer respeito a todo o conjunto de investigações acerca dos usos e das aplicações silogísticas.

${ }^{28}$ Ver, por exemplo, as aproximações sistemáticas entre as quatro formas de uso dos silogismos e as obras em que foram estudados: Refutações Sofísticas, 2, 165b1-11; Tópicos, I, 1, 100a25-101a24. 
como uma espécie de preâmbulo, sendo Da interpretação considerado como espúrio e, portanto, só inserido ao Órganon posteriormente.

Para entendermos a tentativa de fazer reunir sob o tratado Órganon obras de Retórica e Poética, tentativas que haviam influenciado as duas indicações a que Carvalho se referiu, é preciso ter em mente que o acréscimo do âmbito lógico, aos três costumeiramente referidos por Aristóteles, parece ter advindo do embate com a filosofia estoica, que dividira a filosofia em três âmbitos: lógica, ética, física ${ }^{29}$. Ocorre que a noção de lógica no estoicismo é mais ampla que a presente em Aristóteles, de modo a abrigar estudos de psicologia e de ontologia. Uma tal noção, em grande parte, aproxima-se da dialética em sentido platônico, o que nos sugere, dirá Mesquita, ter sido o platonismo a fonte comum para os termos com que estoicos e peripatéticos pretendiam dividir a filosofia: "foi pois provavelmente por contaminação académica que a secção lógica se viu integrada na classificação original" ${ }^{\prime 30}$. Nessa divisão platônica da filosofia, ao lado dos âmbitos teórico e prático é posto um terceiro, dito lógico, a fim de, pela influência sobre a classificação da obra aristotélica, reunir explicitamente todos os estudos silogísticos, incluindo, nesse caso, o entimema retórico. Percebe-se, no entanto, que a tentativa dos peripatéticos de se colocarem diante do debate da época usando termos não aristotélicos leva-os a, por um momento, abandonar o âmbito do saber poiético.

Se o debate da época força o Liceu a adotar um âmbito de estudos lógicos, que torna possível uma classificação das obras aristotélicas segundo a divisão da filosofia proposta fora de seus muros, o ponto-chave dessa influência será observado justamente na posterior decisão de assumir o âmbito lógico como acréscimo aos outros três, estes inerentes à divisão do saber feita por Aristóteles - o que, bem compreendido, não subverte a estrutura aristotélica, mas a complementa. Tal acréscimo, evidentemente, não se faz considerando a lógica uma ciência ela mesmo: e a razão é que cada ciência se determina por um fim, de modo que a tríade dos saberes os distingue entre si pelas distintas relações mantidas com esses fins (o fim pode ser o conhecimento ele mesmo [teórico] ou algo externo a ele: nesse caso, ou ele visa uma ação [prático] ou a produção de algo distinto da ação [poiético $]^{31}$ ). Frente a essa tríade científica, o âmbito da lógica, pontua

\footnotetext{
${ }^{29}$ Cf. DIÓGENES LAÉRCIO, Vidas, II, 35-44. Sobre o embate de ideias durante a vigência do Liceu, Mesquita pontua a maneira pela qual os peripatéticos, sem o recurso às obras de aula do mestre, viram-se envolvidos em discussões cujos termos eram ditados cada vez mais pelos estoicos, o que parece justificar a tentativa de classificar as obras e os estudos aristotélicos a partir da tríade estoica que explicitamente não reconhece o âmbito da poiética, razão pela qual a Retórica, e a Poética por extensão, eram situadas sob o âmbito da lógica. ${ }^{30}$ Segundo Mesquita (Mesquita, Pedro. Introdução geral: As obras completas de Aristóteles. Lisboa, INCM, 2005, p. 280), essa influência estaria testemunhada pela divisão da filosofia proposta por Xenócrates (o líder da Academia platônica durante todo o tempo de atuação do Liceu aristotélico), já que não há em Platão qualquer classificação das ciências, fundada numa sua constituição disciplinar, por assim dizer.

${ }^{31}$ Cf. ARISTÓTELES, Ética a Nicômaco, I, 1, 1094a3; VI, 5, 1140a31-b7; Metafísica, I, 2, 981b13-16.
} 
Mesquita, seria propriamente sem finalidade, e exatamente por isso serviria como um meio, como instrumento (órganon) a partir do qual se desenvolve cada ciência determinada:

Quer dizer, a finalidade do conhecimento lógico não pode ser descrita nem como residindo no próprio conhecimento, nem como residindo na realização de algo exterior a esse conhecimento, porque reside inteiramente no suporte metodológico que presta à concretização das finalidades das outras áreas de conhecimento/32.

A construção do Órganon por Andrônico de Rodes, portanto, constitui-se na tentativa de organizar não o conhecimento aristotélico, e sim as obras de Aristóteles, a partir de uma concepção acerca do conhecimento; e em face da qual se faz legítimo alocar o estudo lógico ao lado dos demais, como um escopo discursivo, indicado por Aristóteles, no qual a ciência se estabelece: "nem à investigação [tês skopúses] que estuda a demonstração [apodeíxeós] e a ciência [epistémes], pois esta investiga justamente esse gênero de objetos" ${ }^{\prime 33}$. Dito de outro modo, a classificação das obras em Andrônico inspira-se na categorização do conhecimento, não o contrário. Por esse motivo, o saber lógico é digno de ter lugar relevante na classificação, pelo fato de estar destacado da tríade das finalidades, como uma condição de possibilidade para a realização delas ${ }^{34}$. Eis a razão de Andrônico se sentir autorizado não apenas a reunir diferentes estudos em um tratado único, nomeado depois Órganon por Alexandre de Afrodísia e apresentado como saber instrumental, mas também a defini-lo como preâmbulo necessário às demais ciências, apresentado então como estudo introdutório. Essa é, por certo, também a razão de haver situado Retórica e Poética não como lógicas, e sim como produtivas ou técnicas, pois se fossem lógicas elas seriam sem finalidade, o que evidentemente não é o caso.

Não sendo nova, portanto, a proposta de alocar Retórica e Poética como obras lógicas, é necessário dizê-la evocar, fundamentalmente, intenções neoplatônicas e estoicas, inscritas sob uma divisão da filosofia não subscrita

\footnotetext{
${ }^{32}$ MESQUITA, ob. cit., p. 285.

${ }^{33}$ Metafísica, XI, 1, 1159b18-20. Uma outra passagem, ao que parece sem precedentes no corpus aristotélico, menciona o âmbito da lógica como dotado de relativa autonomia (Tópicos, I, 14, 105b19-25): “Das proposições e problemas - encarando-se a questão em linhas gerais - existem três grupos: algumas proposições são éticas, outras são físicas e outras são lógicas. [...] um exemplo de proposição lógica é: 'o conhecimento dos opostos é ou não é o mesmo?'”. DÜRING, Ingemar. Aristotele. Traduzione italiana di P. Donini. Milão, U. Mursia editore, 1978, assevera, contudo, que essa forma de se entender o uso do termo logiké não se faz em vista do que hoje se entende por lógica, mas em vista de um tipo de problemática discutida à época em que Aristóteles escrevia sua obra, e que muito provavelmente se referia a discussões com os estoicos quanto ao âmbito linguístico (ob. cit, p. 68). Para uma possível indicação da ideia de lógica como introdução e propedêutica a outros estudos, ver Metafísica, IV, 3, 1005b2-5.

${ }^{34}$ Cf. ARISTOTELE. Organon. Coordinamento e introduzione generale de Maurizio Migliori. Milano, Bompiani, 2016.
} 
pelo vocabulário da filosofia aristotélica. Quando Carvalho procura trazê-la novamente à cena, sem dar mostras de conhecer o debate sobre a lista das obras que compõem o corpus de Aristóteles, já que pretende aventar a possibilidade de reestruturá-las quanto ao Órganon, ele está, entre outras coisas, subvertendo o princípio aristotélico de classificação seguido pela tradição, na esteira de Andrônico de Rodes ${ }^{35}$. É uma impropriedade dizer não serem Poética e Retórica nem teoréticas, nem práticas, nem técnicas, porque ao defini-las como introdutórias, pretende-se concebê-las como estudos sobre o lógos enquanto condição de possibilidade das ciências. $\mathrm{O}$ caso da Retórica, geralmente tido como mais afinado àquela perspectiva discursiva que encontramos no Órganon, porque anunciada por Aristóteles como a outra face da Dialética ${ }^{36}$, tende a se distanciar da instrumentalidade lógica por se apresentar como um saber cujo objetivo está em produzir persuasão - em vista da qual o orador deve levar em consideração não só o lógos, enquanto um tipo de silogismo, mas também a léxis, o modo de dizer, bem como o páthos, o estado de ânimo da audiência, e o éthos, a credibilidade do orador frente à sua audiência. A Retórica como técnica, portanto, se justifica sob a perspectiva de estudos, por assim dizer, intersubjetivos $^{37}$. Foi o que Paul Ricoeur conseguiu condensar num pequeno parágrafo de sua obra sobre a metáfora:

Além disso, a retórica não pode ser esgotada em uma disciplina puramente argumentativa, pois está voltada para o ouvinte, e não pode, portanto, deixar de considerar o caráter do falante e a disposição da audiência; em poucas palavras, ela permanece na dimensão intersubjetiva e dialogal do uso público do discurso, donde resulta que a consideração das emoções, das paixões, dos hábitos e das crenças continua a ser da competência da retórica, mesmo que ela não deva suplantar a prioridade do argumento

\footnotetext{
${ }^{35} \mathrm{O}$ estudo principal desse debate deve-se a Moraux ( $o b$ cit.), em face do qual procuraram se posicionar diversos estudos, como o artigo de DÜRING (“Aríston or Hermippus?", 1956), para criticá-lo, e o de KEANEY ("Two Notes on the Transmission of Aristotle's Writings", 1963) para apoiá-lo. A tendência atual é a de apoiar as análises de Moraux, como se pode ver em GUTHRIE (A History of Greek Philosophy, 1962) e LORD ("On the Early History of the Aristotelian Corpus", 1986). Não é preciso dizer que Carvalho poderia, e deveria ter consultado essas obras, antes de propor uma alteração do Órganon.

${ }^{36}$ Cf. Aristóteles, Retórica, 1354a. Mesmo os que assumem a ideia de os estudos 'lógicos' aristotélicos terem surgido a partir da eficácia do discurso persuasivo pretendem apresentá-los por oposição ao interesse retórico (cf. ARISTÓTELES, Tratados de Lógica II. Órganon. Introducciones, traducciones y notas de Miguel Sanmartín. Madrid, Gredos, 1988), tendo em vista o objetivo de Aristóteles em cada vez mais aprofundar os estudos acerca de um discurso adequado à 'ciência' (epistéme). Sobre essa proximidade da Retórica e do Órganon, ver ainda a introdução de Migliori em Aristotele (Organon).

${ }^{37}$ Uma amostra do tipo de pretensão olaviana em tomar a Retórica como ciência do discurso pode ser destacada da sua introdução feita à dialética de Schopenhauer, em que se mostra o equívoco de tomar a técnica persuasiva simplesmente como estudo dos argumentos: “a retórica excluía de seu campo de estudo os dois primeiros [a pessoa do orador e os fatos de que se fala] e se concentrava nos argumentos" (Schopenhauer, Arthur. Como vencer um debate sem precisar ter razão. Dialética Erística. Introdução, comentários e notas de Olavo de Carvalho. São Paulo, Topbooks, 1997, p. 35).
} 
verossímil, pois o argumento propriamente retórico dá conta ao mesmo tempo do grau de verossimilhança relativo à maioria discutida e do valor persuasivo relativo à qualidade do falante e do ouvinte ${ }^{38}$.

Se não parece aristotelicamente adequado aproximarmos a Retórica do Órganon, a distância é ainda maior no caso da Poética. Ainda que o termo em grego que dá título à obra sugira uma relação com o discurso (perì poietikés, sobre o fazer poesia), o estudo aristotélico orienta-se em vista de todo um conjunto de aspectos em relação aos quais a criação poética se realiza, e em vista da qual se apresentam articulados por certo modo de reprodução que encontra seu conceito na mímesis. Reproduzir talvez não seja o melhor termo para traduzir mímesis, mas o utilizo para fazer referência tanto à noção cara ao termo poiésis (a de produzir, sempre a partir de algo dado), quanto à noção de fazer sobre algo já feito, portanto um refazer de outra maneira. A atividade mimética, que em Aristóteles é o fundamento de todas as artes poéticas, articula um processo criativo de se reatualizar o que houve, o que se passou, não em vista do que de fato ocorreu, mas em vista do que nele há de universal. Esse universal, no entanto, não diz uma lógica, e sim uma ética: "universal é o que se apresenta a tal tipo de homem que fará ou dirá tal tipo de coisa em conformidade com a verossimilhança e a necessidade; eis ao que a poesia visa" (Poética, 1451b 8-10). Quando a tragédia, por exemplo, imita ações de homens valorosos, sua mímesis reproduz qualidades morais, e não o faz de modo lógico; nem a Poética, ao refletir sobre a tragédia, destaca qualquer interesse em servir como introdução à ciência do discurso, mostrando-se, antes, como técnica para a realização e a compreensão dos espetáculos teatrais que reproduzem, de maneira eficaz, o universal dos valores humanos a fim de produzir catarse. Não deixa de ser significativo que, em toda a proposta de Carvalho, ele simplesmente se esqueça do conceito central da Poética ${ }^{39}$.

Diante do alegado preconceito produzido pelo modo de Andrônico organizar as obras aristotélicas, o que se percebe é, antes, que o único preconceito existente aqui parece ser o de forçar as duas obras técnicas de Aristóteles, a Retórica e a Poética, para funcionarem como teorias do discurso. De todo modo, fica claro haver, por essas e outras questões possíveis de ser levantadas, certas intenções e valores de fundo nessa proposta olaviana, cuja sustentação parece querer recorrer, em maior ou menor escala, à autori-

\footnotetext{
${ }^{38}$ RICOEUR, Paul. A metáfora viva. Tradução Dion Macedo. São Paulo, Loyola, 2015, p. 53. ${ }^{39}$ Sobre a mímesis como conceito estético para a reprodução artística do éthos, do páthos e da práxis, ver BUTCHER, Samuel. Aristotle's Theory of Poetry and Fine Art. London, Macmillan \& Co, 1932, p. 121ss. Essa ausência a que me refiro foi notada por um parecer avaliativo feito pela SBPC à época, e que Carvalho anexou à edição da sua obra (Carvalho, Aristóteles em Nova Perspectiva, p. 157) sem o ter, no entanto, respondido efetivamente quanto ao seu nenhum tratamento dos conceitos de mímesis e katársis na descrição da Poética - logicamente porque, enquanto técnica, a Poética objetiva compreender o fenômeno identificado por esses dois conceitos, antes de ser uma obra sobre a lógica da possibilidade, como o quer Carvalho.
} 
dade aristotélica. Até aqui, ficamos com a certeza de que a inversão dos parâmetros interpretativos fundamentais se constitui, a bem da verdade, em método para Carvalho - que se compraz em criar a confusão expositiva como uma proposta educativa, segundo suas próprias palavras.

"Ademais, existe algum mérito pedagógico em não ser bem arrumadinho, em poder dispor os dados não na ordem mais costumeira em que os desejaria o espectador preguiçoso, mas em desarrumá-los inteligentemente de modo a obrigar o leitor a tomar parte ativa na investigação" ${ }^{\prime 40}$.

\section{c. Justificativas interpretativas: usos [retóricos] do discurso}

Mas afinal, não tendo a Poética nem a Retórica em Aristóteles a condição de fazerem parte do tipo de saber instrumental, sem finalidade específica, dos tratados agrupados no dito Órganon, sob que critérios Carvalho se pôs a reviver uma hipótese neoplatônica, declaradamente confundindo a lógica e a ciência aristotélicas? O próprio autor parece suspeitar de toda suspeita inevitável, e se adianta para elencar três motivos principais para justificar o valor e a importância de sua teoria sobre os quatro discursos em Aristóteles, que parafraseio aqui:

1. As quatro ciências do discurso tratariam das quatro maneiras pelas quais um homem pode agir sobre o outro (guardemos essa expressão) por meio de quatro níveis de credibilidade: possível, verossímil, provável e certo, reunidos num tipo de escala crescente. "Possibilidade, verossimilhança, probabilidade razoável e certeza apodíctica são, pois, os conceitos-chave sobre os quais se erguem as quatro ciências respectivas" (Carvalho, Aristóteles em Nova Perspectiva, p. 40).

2. Haveria ainda, por parte de Aristóteles, uma descrição igualmente crescente das diferentes disposições psicológicas correspondentes ao ouvinte de cada discurso (Ibidem, p. 41), ou seja, uma espécie de divisão dos quatro públicos a que se destinariam os discursos: o espectador, no caso poético; o juiz, no retórico; o investigador, no dialético; e o discípulo, no lógico (os termos para cada ouvinte são de minha responsabilidade).

3. Enfim, as duas escalas guardam correspondência com a teoria aristotélica do conhecimento: dos dados dos sentidos, forma-se pela memória ou imaginação um grupo de imagens (eikon) segundo suas semelhanças. Com base nessas imagens, a inteligência opera a fim de construir os esquemas eidéticos, os conceitos, com os quais, por fim, constrói os juízos e os raciocínios. Essa subida dos sentidos até os juízos esquematiza, no entender de Carvalho, os graus crescentes dos discursos, do poético ao lógico.

${ }^{40}$ CARVALHO, O imbecil coletivo, op. cit. p. 33. 
Temos aqui, portanto, em resumo, a motivação de Olavo de Carvalho para confundir a estrutura da obra aristotélica. Tanto a primeira quanto a segunda justificam a circunscrição da teoria do lógos do Estagirita a uma espécie de teoria do poder como seu fundamento, pela qual se deve dizer que a finalidade do conhecimento está na ressonância de credibilidade que o juízo é capaz de reverberar em determinado tipo de ouvinte, embora o Órganon indique, em vários momentos, que uma teoria do lógos só pode ser pensada em termos de uma teoria do conhecimento ${ }^{41}$. O que Carvalho propõe é uma inversão da lógica epistêmica. Se quem conhece verdadeiramente alguma coisa precisa, ao mesmo tempo, estar certo dessa verdade, o inverso da implicação não se dá necessariamente: acreditar que sabe não garante a verdade do que se diz saber. Em outras palavras, seria impróprio determinar o discurso em Aristóteles face à convicção (pístis) e não ao saber (epistéme), pois o próprio lógos, em $D a$ Interpretação, interessa ao estudo em razão de seu caráter apofântico, de afirmar ou negar algo que pode ser verdadeiro ou falso ${ }^{42}$. Verdade-falsidade, nesse sentido, é o único juízo de valor possível, e desejável, à investigação filosófica do conhecimento - e se a Dialética lida com premissas geralmente assumidas como verdadeiras (endóxa) é porque sua tarefa será exatamente a de demonstrar a verdade ou falsidade delas ${ }^{43}$.

Vejamos, como exemplo, o caso da Poética. Carvalho pretende fazê-la instrumento de uma teoria do discurso na qual lhe cabe produzir credibilidade do que é realmente possível, e isso a partir de uma leitura equivocada da descrição feita por Aristóteles: a frase nos diz que "a tarefa do poeta não é a de dizer o que de fato ocorreu", algo próprio à História, e sim "o que poderia ocorrer dada a verossimilhança e a necessidade" (tà dynatà katà tò eikòs è tò anankaion. Poética, 1451a 39-40). Se tivéssemos que pensar na convicção do espectador, esta seria dada não pelo possível, mas pela verossimilhança e necessidade, bem distinta da gradação proposta de Carvalho. Mas o possível, nesse caso, não se define em vista dos fatos, e sim do enredo (mythos), enquanto produção mimética. Não se compreende a distinção entre poesia e história se não se entende a preocupação central daquela não com os fatos, mas com o enredo. Ela pode mesmo representar o impossível, desde que seu mythos tenha coerência com sua finalidade: "pois não saber que a corça não tem chifres é menos grave do que pintá-la de modo não mimético" ${ }^{\prime 4}$.

\footnotetext{
${ }^{41}$ Para uma apreciação sobre esse ponto, ver toda a primeira parte de MODRAK, Deborah. Aristotle's theory of language and meaning. Cambridge, Cambridge University Press, 2001 (especialmente p. 84-114).

${ }^{42}$ A indicação aristotélica, inclusive, ratifica a separação do trato que cabe ao estudo 'lógico' daquele que cabe às técnicas retórica e poética: "Todos os discursos são significativos, não como ferramenta (órganon), mas, como já tinha sido dito, por convenção; nem todo discurso é declaratório (apophantikòs), mas apenas aquele em que subsiste o verdadeiro e o falso. (...) Deixemos os outros discursos, pois o exame deles é mais próprio à retórica e à poética. Porém, o declaratório é próprio deste estudo"; Da Interpretação, IV, 16b33-17a7.

${ }^{43}$ ARISTÓTELES, Tópicos, II, 101a34-101b4.
} 
Esse fazer mimético, que no caso da tragédia procura produzir a catarse do temor e da compaixão em seus espectadores, sendo apropriado ao âmbito no qual ele ocorre como espetáculo, de forma alguma encontra na reflexão aristotélica uma atribuição inferior à dos tribunais ou do Liceu, como alega Carvalho ao considerar que o Estagirita deixa latente certa compreensão do discurso em que haveria entre o expectador da poesia e o aluno de um professor que demonstra suas teses um caminho ascendente, quando o que há entre a poética dos espetáculos e o ensino é simplesmente uma diferença de ambiente e de objetivos. Não deveríamos esquecer, além disso, que o filósofo, capaz de felicidade, é aquele que contempla a verdade: contemplar, em grego theorên, é termo oriundo da experiência teatral, numa clara proximidade entre as atitudes do espectador e a do filósofo, a mesma proximidade que Platão acentuou em República VI, e que o próprio Aristóteles ratificaria ao indicar haver algo de filósofo no amante dos mythos ${ }^{45}$.

A última das razões, e por certo a mais interessante, alega haver do poético ao lógico uma gradação similar à que existe da percepção sensível ao pensamento conceitual. Segundo a descrição de Carvalho, a maneira pela qual Aristóteles entendia o modo de conhecer segue o caminho da sensibilidade, passando pela produção de imagens ou representações mentais das coisas, até que a mente passa a construir esquemas eidéticos aproximando os semelhantes, a fim de formar os conceitos, a grande conquista da lógica. Acentuando esse caráter gnosiológico unitário, Carvalho aponta para o que seria sua organicidade crescente: "o conhecimento é para Aristóteles um processo unitário, orgânico, que se eleva progressivamente desde as formas elementares, comuns ao homem e ao animal, até as grandes sínteses da ciência e da filosofia" ${ }^{46}$. Sua intenção, desde logo, se esclarece:

Quero chegar à conclusão inevitável de que, se o processo cognitivo, para Aristóteles, é uma unidade orgânica que vem das sensações, passa pela imaginação, se eleva ao pensamento e chega à organização racional do mundo, sem salto nem descontinuidade, do mesmo modo o método do conhecimento, o Organon ou instrumento metodológico que estrutura a atividade científica, deveria ser também uma unidade coesa, a expressão de um organismo em evolução sem hiatos. Ele deveria abarcar todas as modalidades de conhecimento, do sensitivo ao racional, estabelecendo os elos e passagens de um a outro, bem como as conversões e retornos, de modo que víssemos as etapas desenvolvendo-se umas de dentro das outras, sem ruptura. ${ }^{47}$

\footnotetext{
${ }^{44}$ ARISTÓTELES. Poética, 25, 1460b 32-33. Nesse capítulo, por sinal, o Estagirita se dedica a responder diversas questões sobre o erro na poesia, geralmente creditado aos absurdos (impossível, adynaton) ditos pelos poetas. Sobre a função da arte e de sua verdade na mímesis, ver ainda Butscher (Aristotle's Theory of Poetry and Fine Art. London, Macmillan \& Co, 1932, p. 165-168).

${ }^{45}$ ARISTÓTELES. Metafísica, I, 982b 17-19.

${ }^{46}$ CARVALHIO, Aristóteles em Nova Perspectiva . ob cit. p. 68.

${ }^{47}$ Ibidem, p. 73.
} 
Em outras palavras, a epistemologia aristotélica postularia a mesma organicidade que estaria pressuposta no Órganon, em termos de discurso, e em vista da qual se estabeleceria o instrumental lógico-metodológico em direção a um saber fundamentado na realidade sensível. Se voltarmos à sua afirmação de que as escalas descritas em 1 e 2 "guardam correspondência" com esta última, a bem dizer a única presente em Aristóteles ${ }^{48}$, percebemos de que modo há no Estagirita a possibilidade, desejável para Carvalho, de compreendermos o Órganon como um tratado esquemático da organicidade epistemológica do conhecimento, em relação ao qual haveria de se perceber a falta dos estudos aristotélicos para os processos anteriores ao conceito: seriam estes, propriamente, a Poética e a Retórica.

Segundo essa leitura, a Poética, a primeira das "lógicas do discurso", corresponderia à apreensão sensível da realidade, mas lamentavelmente a Poética, pelo menos a aristotélica, define-se como um estudo sobre os espetáculos miméticos de ações humanas, nada dizendo acerca das coisas como elas são realmente. Mais ainda, a mímesis, em seu traço reprodutivo, é não apenas realizada em vista do universal, cujo apelo é moral, como também exige, antes, a atuação da imaginação, no papel central de fantasiar, de representar ações de outros com finalidade educativa ${ }^{49}$. Talvez Carvalho estivesse disposto a assumir um salto das percepções sensíveis à phantasía, baseando-se numa explicação de ser a imaginação aquela responsável por cognitivamente organizar as percepções variadas dos sentidos em uma única referência ôntica ${ }^{50}$. Se a Poética é, de acordo com esse pressuposto, uma lógica da fantasia, a que tipo de "lógica" então corresponderia a Retórica? Não seria, ela também, uma lógica imaginativa, na medida em que se vale da verossimilhança e pretende conduzir seus ouvintes a ação? Mas não é exatamente o poético que se realiza em vista da verossimilhança e da necessidade para Aristóteles? Afinal, que função epistemológica seria apropriadamente realizada pela ordem do discurso retórico, senão a da deliberação? Mas não cabe à Dialética a função de auxiliar a deliberação, ao produzir uma investigação sobre o juízo verdadeiro? Que confusão é essa? ${ }^{51}$

\footnotetext{
${ }^{48}$ CARVALHO Ibidem, p. 69-73) pretendeu oferecer duas outras organicidades, em seu entender, correspondentes à epistemológica: a antropológica e a cosmológica. Mas o status hierárquico estabelecido pela definição de humano frente aos demais animais, ou pela escala dos entes reais, só possui correspondência com as etapas do conhecimento porque destas se fazem dependentes: em outras palavras, a compreensão de si e do mundo passa por ser, fundamentalmente, uma compreensão, portanto um conhecimento regido pelas etapas do conhecer. Não há, desse modo, nenhuma novidade na indicação feita pelo autor.

${ }^{49}$ Tratei sobre isso em ALENCAR, Cesar de. "A maturidade simbólica: da ciência ao mito". Veritas (Porto Alegre), v. 65 (3), p. e35275, 2020.

${ }^{50}$ Cf. MODRAK, ob. cit. p. 222-237.

${ }^{51}$ Em formulações feitas em outros momentos de sua obra, Carvalho parece de fato situar a Poética no âmbito das percepções sensíveis, ao passo que caberia à Retórica o lugar epistemológico da imaginação, como o autor esclarece logo ao início de seu curso sobre Husserl, ministrado entre 1992 e 1993, recentemente editado (CARVALHO, Olavo de. Edmund Husserl. Contra o psicologismo. Campinas, Vide Editorial, 2020, p. 15). A passagem, no entanto, é
} 
Isso se deve, naturalmente, a uma projeção, sobre a obra de Aristóteles, de princípios que lhe são estranhos, ao menos segundo a perspectiva do que Aristóteles nos ensina em suas obras. Talvez a proposta de uma hermenêutica não textual seja mesmo a razão dessa projeção. Em todo caso, o que se apresenta, quero crer, encontra na retórica o contexto fundamental para entendermos as intenções e os valores de Carvalho. Porque as duas primeiras razões por ele elencadas são de ordem retórica: falar de modos pelos quais alguém atua sobre o outro e considerar as obras em vista dos ouvintes almejados é só uma maneira retórica de lidar com os discursos. A bem da verdade, é a própria Retórica aristotélica que expõe a consideração pela performance oratória em vista tanto dos tipos de ouvinte a que se destina um discurso como também o modo pelo qual a persuasão se produz como a atuação do orador sobre seus ouvintes (o que acontece no caso da Dialética), a fim de levá-los a determinadas ações (o que não acontece necessariamente no caso da Dialética). Ao considerar a estrutura dos discursos em Aristóteles, Carvalho denuncia como justificativa o intuito de articulá-los não em vista da orientação filosófica sobre os tipos de conhecimento, como toda a tradição veio fazendo desde Andrônico, mas de uma epistemologia retórica, se a expressão é cabível: ou seja, como se o discurso estivesse relacionado com conhecimento simplesmente para efeitos de exercício de poder. Talvez Carvalho estivesse lendo Aristóteles como autor do Novo Órganon ${ }^{52}$.

\section{Aristóteles lendo Carvalho: uma hermenêutica da proposta dos discursos}

A confusão de termos pela qual Olavo pretende sistematizar a filosofia de Aristóteles, e cuja interpretação se baseia, desde o início, em certa implicação psicológica de se buscar o não dito como explicação do que é dito, e não o contrário, como procede a Hermenêutica, faz repercutir sobre o Estagirita uma preocupação filosófica dupla: a de que uma organização das diversas manifestações do lógos, reunidas sob a unidade do Órganon,

confusa, se tentarmos compreendê-la à luz das referidas obras aristotélicas: ao conferir à Poética o papel enraizado nas percepções sensíveis, ela se apresenta igualmente projetada até o desenvolvimento completo das imagens e dos desejos que essas imagens provocam, e que, portanto, reuniria também a phantasía; de modo que à Retórica caberia pôr em confronto as imagens do desejável, que ocorre no âmbito não da imaginação, mas da deliberação. Ver Aristóteles, De Anima, III.

${ }^{52}$ A referência, mesmo irônica, nada tem de casual: Francis Bacon (1561-1626) é mesmo conhecido, enquanto o último dos antigos e o primeiro dos modernos, como havendo criticado a contemplatividade do conhecimento, de pouco ou nenhum efeito prático para a vida dos homens. A ilustração da sua concepção utilitária do saber ficou emblemática na frase "saber é poder" (palavras que, não tão ironicamente, encontram-se no título de um novo curso oferecido por Carvalho recentemente). 
deixa latente certa natureza essencialmente retórica do discurso; a de que, por outro lado, essas manifestações discursivas deveriam seguir o padrão aristotélico da formação conceitual abstrativa. Propor essa preocupação dupla, na verdade, é uma forma de substituir a disposição do Órganon de Aristóteles segundo a perspectiva dos tipos de conhecimento, levada a cabo por Andrônico de Rodes, por uma perspectiva focada na linguagem como território de atuação política. Essa proposta, considerada em sua justificação, nos lança em meio ao enigma da interpretação de Carvalho sobre Aristóteles: enquanto ele considera a potência do discurso priorizando as qualidades intersubjetivas da performance retórica (pois o discurso é descrito em sua essência em termos de credibilidade e de poder de influência sobre os ouvintes, dois aspectos próprios ao modo retórico de produzir persuasão), pretende também reduzir os tratados de Poética e Retórica a meros estudos instrumentais, como atualizações cientificas desse discurso potencialmente retórico. Se é preciso inserir, no âmbito lógico do Órganon, as produções poéticas e retóricas como sendo instrumentos utilizados pelas ciências em geral, por que razão a estrutura lógica do discurso é basicamente descrita em termos retóricos, e não analíticos, como seria de se esperar, dado o papel lógico-científico do Órganon na proposta de Carvalho?

O enigma de sua reflexão encontra expressão mais clara no capítulo quatro da análise dos quatro discursos. Na oportunidade, ele se propõe a demonstrar a universalidade da teoria aristotélica do discurso de um modo não aristotélico, recorrendo ao que ele toma como uma autodemonstração universal do discurso, por meio de uma suposta estrutura lógico-analítica daquilo que "a filologia sugere pela interpretação dos textos e a dialética sustenta pela exclusão das hipóteses contrárias" ${ }^{\prime \prime 3}$. Essa autodemonstração definiria os conceitos básicos de toda atualização discursiva, a fim de nos fazer concluir que o discurso, qualquer que seja sua atualização, é potencialmente "o trânsito do acreditado ao acreditável, por meio de um encadeamento de nexos" (Ibidem, p. 86). Se o encadeamento que dá lógica ao discurso é descrito em termos analíticos, ou seja, pela vinculação necessária entre premissas e conclusão - o que é já uma impropriedade, pois assume que todo discurso é basicamente um silogismo -, tal encadeamento se justificaria, segundo Olavo, pela finalidade de produzir uma modificação no ouvinte: a suposta estrutura lógica dessa autodemonstração assume, aqui, uma razão de ser persuasiva, e o discurso dito eficaz será o que for capaz de obter do ouvinte a credibilidade, que se explicaria como a aceitação dessa modificação produzida. A potência comum às manifestações do discurso, no fim das contas, se resumiria à capacidade de alguém exercer poder sobre outrem através das palavras - e sendo esse poder o ponto-chave para a compreensão da proposta de gradação entre as variadas manifestações do discurso, Carvalho reduz a preocupação com o saber (epistéme) à mera produção de convicção (pístis).

${ }^{53}$ CARVALHO, Aristóteles, ob. cit. p. 84. 
O resultado de uma demonstração não aristotélica do tipo de potência discursiva que Carvalho pretende compreender atualizada em quatro tipos na obra de Aristóteles mostra-se, ao final, exatamente o que ela é: a demonstração, não aristotélica, daquilo que se pretende atribuir a Aristóteles. Estamos, desde sempre, no âmbito do pensamento de Carvalho, para quem o lógos só pode ser compreendido em termos de exercício de poder. Essa constatação hermenêutica de suas intenções (porque derivada dos textos de Carvalho e não de implicações sobre o que ele não disse), é capaz, quero crer, de justificar os modos e os meios de atuação do autor por meio não só de seus livros, mas sobretudo dos canais em redes sociais, responsáveis pela maior difusão de suas ideias. Formulemos nossa constatação interpretativa: Carvalho reduz os tipos de discurso à sua potencial eficácia retórica, a ser obtida sobre o ouvinte no intuito de modificá-lo, e para isso pretende inserir a Retórica e a Poética no conjunto do Órganon aristotélico, a fim de legitimá-las como estratégias variadas da mesma lógica, com o intuito de tornar científica toda finalidade persuasiva, ao mesmo tempo em que confere finalidade persuasiva a toda forma de ciência. Isso explica sua impertinente tentativa de forçar o Órganon a acumular funções de poética e retórica, para estabelecer a ciência e o debate de ideias como inescapáveis ao interesse político da eficácia retórica - que para ele tem de ser erística, pois o que conta é vencer sem precisar ter razão.

Isso nos esclarece, por exemplo, seus interesses na proposta de tradução da erística dialética de Schopenhauer, que Carvalho assumiu ao mesmo tempo como prolongamento de sua teoria dos quatro discursos e como uma "galeria de maus exemplos" de como reduzir o adversário ao silêncio, reunidos pela providencial oportunidade que lhe chegou de publicar os apontamentos feitos pelo filósofo alemão - não para, diz Carvalho numa nota prévia, "induzir o leitor a discutir com outros, mas a dialetizar consigo próprio" ${ }^{54}$. Seria um nobre objetivo, se o autor, na mesma introdução, não denunciasse taxativamente regozijar-se em ver surgir "por toda parte a suspeita e a discórdia, elevando os alunos contra seus mestres, os eleitores contra seus candidatos, os leitores contra os jornais, os espectadores contra as emissoras de TV" (Ibidem, p. 24). Esse estado de suspeita e de discórdia, almejado pela tradução da erística de Schopenhauer a partir do esquema da visão dos quatro discursos, resume um propósito político de levar seus leitores a não mais aceitarem, ao final, a defesa legítima de opiniões, tomando-as como "insuportável e repugnante intrujice". Desse suposto esforço em conduzir a alma do leitor a dialogar consigo mesma e com sua consciência, as intenções de Carvalho transparecem, com um

\footnotetext{
${ }^{54}$ SCHOPENHAUER, op. cit., p. 17. Vale aqui a ressalva de que Carvalho, que assina a tradução do original alemão, parece ter feito, na verdade, a transcrição para o português, sem autorização ou qualquer indicação expressa, da tradução feita em espanhol por Dionísio Garzon. Sobre a polêmica, ver o artigo de TROSTER [https://www.cartacapital.com.br/ opiniao/a-patifaria-intelectual-de-olavo-de-carvalho/ último acesso 29.04.2021].
} 
pouco de atenção na leitura, determinadas por um propósito de insuflar o impedimento do debate por uma via dupla: a de forjar, para seus leitores, a impressão de que, ao possuírem o conhecimento sobre as estratégias do jogo sujo do debate de ideias, estariam situados acima das intelectualidades de todo tipo; a de provocar, devido a essa impressão que impede a busca pela verdade no diálogo, uma ainda maior atomização de seus leitores, pondo-os à parte da sociedade e do jogo democrático - o que favorece o clima verborrágico, característico da opinião única e da emergência de notícias falsas como arma política, além de nutrir "a inclinação de procurar as verdadeiras forças da vida política naqueles movimentos e influências que os olhos não veem e que atuam por detrás das cortinas" ${ }^{\prime \prime 5}$.

Tal impressão expõe-se mesmo como finalidade da sua conhecida obra de polemista, $O$ imbecil coletivo. No intuito de denunciar o tipo de emburrecimento protagonizado pelos intelectuais tupiniquins, Carvalho destaca, mais uma vez apenas ao leitor atento, seus valores e suas intenções. Ao acompanhar de perto os três prólogos desta obra, torna-se cada vez mais clara, embora mais complexa, a imagem que o autor tece de si mesmo e da sua obra - como se fizesse, não posso deixar de sugerir, uma transição simbólica do discurso dialético até um de tonalidade mais poética, descendo e subindo na escalada das credibilidades para atordoar o juízo do leitor em um fascínio e um encantamento que subjuga e silencia ${ }^{56}$. Se

${ }^{55}$ Essa é uma das características da ralé, o tipo de indivíduo que para Arendt (ARENDT, Hannah. Origens do totalitarismo. São Paulo, Cia das Letras, 1998) está na base dos regimes totalitários, desencadeados por um contexto em que a atomização individual se faz cada vez mais forte: "A atomização social e a individualização extrema precederam os movimentos de massa" (Arendt, ob. cit., p. 130; 366). Sobre a prática de impedir o debate, leiamos as palavras de Carvalho, em vídeo de um de seus muitos hangouts intitulado "Não respeite comunistas, destrua-os" [https://www.youtube.com/watch?v=2dIXgHL7Nl0 último acesso em 29.04.2021], que é ilustrativo do conceito de retórica do ódio em Rocha (ob. cit., p. 37; sobre o conceito, ver p. 157): "Por isso que eu acho que o panelaço é a maior invenção. A coisa mais eficaz que tem no país é o panelaço. Não deixa falar mais! Não deixa falar, não obedeça, não reconheça!". Nada surpreendente, para quem já havia indicado, ao final de sua introdução à dialética de Schopenhauer, que "se a redução da dialética a uma erística pode levar às consequências filosóficas - e não só filosóficas - mais temíveis, também seria impossível excluir da dialética, considerada como meio de investigação, todo aspecto erístico, pela simples razão de que a refutação das proposições errôneas é uma preliminar indispensável de toda investigação filosófica e científica. (...) a tagarelice e a patifaria invadiram a cidadela mesma da filosofia e nela ocupam, não raro, os lugares de comando. É preciso uma luta ativa e sem descanso para expulsá-las. Nesse momento, a erística assume a dignidade de uma arma indispensável no combate filosófico e todos os estudantes de filosofia devem reconhecimento ao pioneirismo e à ousadia de Schopenhauer" (Schopenhauer, op. cit., p. 90; 92; grifo nosso).

${ }^{56}$ Esse trânsito constante entre os tipos de discurso, que aqui procurei explicitar tendo em vista seu fundamento na retórica erística, teve seu efeito encantatório destacado por CUNHA, Martins. A tirania dos especialistas. Desde a revolta das elites do PT até a revolta do subsolo de Olavo de Carvalho. Rio de Janeiro, Record, 2019, que o relaciona ao procedimento analógico da dialética simbólica de Carvalho. Em termos práticos, Carvalho transita do recurso a certos argumentos até o manejo simbólico tanto de metáforas religiosas e literárias quanto de zombaria, caricatura e xingamento, para impedir o debate e assassinar reputações - descrito, de modo lúcido ainda que não filosófico, por DUARTE, Letícia. “Como o olavismo explica 
temos lido esse discurso como erístico, é porque Aristóteles, ao indicar como uma de suas finalidades "reduzir o adversário à impotência", fez questão de apontá-lo pelo seu fim único de obter vitória, diferenciando-se dos sofistas apenas porque estes ganham dinheiro com isso ${ }^{57}$.

No primeiro prólogo, cuja preocupação foi a de mostrar, de maneira sóbria ainda que irônica, o para que veio à luz seu livro, encontramos, ao final, o valor que o autor alimenta em relação às suas influências: dirigir-se "exclusivamente ao leitor individual, na solidão da sua consciência" para fazê-lo admitir "entre quatro paredes, verdades que renega em público". Eis o que chamei de atomização da opinião, suscitada por um traço inexpressável da verdade - e que produz no leitor, ao ter seu próprio juízo confrontado com o poder mágico do discurso de Carvalho, a modificação necessária para assumir, a si mesmo, que o autor está com a razão: ali no coração da noite, onde as palavras não encontram "outro interlocutor senão o silêncio imenso" (O imbecil coletivo, p. 47). O que chamo de poder mágico do discurso de Carvalho (sobre o qual não poderíamos nos debruçar aqui sob pena de alongarmos em demasia nossa temática) foi diagnosticado por Cunha (A tirania dos especialistas, p. 147ss) junto à aplicação constante do recurso discursivo à analogia enquanto fundamento do que Carvalho propôs como sendo sua dialética simbólica, de inspiração esotérica e mística, com a qual atua em sua mais longa obra: o Curso Online de Filosofia $(\mathrm{COF})^{58}$. Com o intuito de conduzir seus alunos ao estranhamento diante da realidade atual e à sensibilização da consciência, cujo propósito declarado é dar corpo, pelo hábito, a uma verdade silenciosa só partilhada por quem

\footnotetext{
o bolsonarismo". Retrato Narrado, 18 de outubro de 2020. [Link de acesso ao podcast: http:// spoti.fi/391wXG0], como método-padrão dos vídeos do escritor contra seus desafetos, e que fora resumido pelo próprio Carvalho no vídeo citado em nota anterior. Em suma, "o gosto pelo vocabulário chulo, pela humilhação pública dos adversários, pela desumanização dos oponentes, só mostra técnicas de efeito retórico para destilar inverdades que, mesmo que posteriormente desmentidas, têm potencial para enganar um número expressivo de pessoas", Hussne (ob. cit.). Sobre as implicações desse método de xingamento e de impedimento do debate, ver também Mello (ob. cit.).

${ }^{57}$ ARISTÓTELES, Refutações Sofísticas, 165b 17; 171b 24.

${ }^{58}$ Criado em 2009, cinco anos após o autoexílio de Olavo no sul da Virgínia (EUA), o COF encontra-se atuante, a despeito da promessa inicial de uma duração de 5 anos, porque, como apontou Cunha (ob. cit., p. 165), é Olavo o centro dessa "nova comunidade de amigos que sairá do 'obscurantismo moderno' e que tem o compromisso de recuperar a 'alta cultura no Brasil"' e, portanto, é ele quem determina o fim do curso. Mas com isso, o curso se tornou um percurso místico sob a tutela de um professor que monopoliza a razão; uma longa marcha da vaca para o brejo, diríamos, inspirados pelo subtítulo de $O$ imbecil coletivo 2 . Pois se um tal compromisso depende do apostolado sustentado pelo professor, é porque aquela unidade da consciência no conhecimento e vice-versa, com que Carvalho pretende definir toda filosofia, no fundo é tão-somente uma unidade do [e no] controle (p. 173), cujo instrumento mágico decorre da utilização simbólica do discurso para adestrar a imaginação (efeitos poético e retórico conjugados à aplicação lógica de conceitos) para precipitá-la ao exercício de uma dialética que cinde o mundo das ideias e o real, a fim de manter esse corpo místico de alunos exilados sob seu domínio e influência - até a morte (p. 182-183).
} 
nutra a mesma consciência, o projeto educacional de Carvalho apresenta-se com a retórica que "cria nas pessoas que pretendem fazer parte dessa nova casta intelectual, direta ou indiretamente, uma espécie de feitiço que aprisiona a consciência. Nesta realidade alternativa, elas são os anti-indivíduos, todos integrantes de algo jamais visto na trajetória recente deste país"59

Esse poder mágico, cujos efeitos em atomizar as consciências são sugeridos em tom dialético no primeiro prólogo, ilustram requintes retóricos em seu prólogo do prólogo. Para auxiliar a credibilidade em vista de determinado tipo de auditório (sempre aquele afeito à cultura judaico-cristã e liberal), Carvalho introduz a imagem de um demônio oculto, que por alguma razão the teria conduzido a nutrir uma atenção diabólica sobre aquelas tolices irritantes que acabou por inventariar ao longo do livro. Confessando um autoengano de causas infernais (como se o autoengano pudesse ter outra causa senão o próprio enganado), o autor amarga perante seu anjo pessoal a crua confissão daquela ânsia, a fim de mostrar aos tolos o sentido de sua tolice: "mostra-os a si mesmos, para que os humilhe o que os lisonjeou um dia"60. Aqui, aquela proposta de diálogo com o leitor individual transmutou-se em proposta de refutação daqueles que dizem saber, como um conselho do anjo que lhe anuncia um bem surgido por acaso de sua obra, como sendo o "efeito da alquimia divina, que pode transmutar em bem até o vício de ler o que não presta"61. Essa frase final do prólogo do prólogo é preciosa, porque situa o discurso de Carvalho sob o efeito do seu fascínio, articulando o mecanismo da retórica erística com a reação emocional pretendida. O vício de ler tolices, alterado alquimicamente, sugere, pela imagem que ilustra a experiência de Carvalho como leitor, que sua retórica intenciona produzir em seus leitores um silêncio incapacitante para denunciar as tolices do próprio autor, nas leituras interpretativas que faz, por lhes haver estimulado o prazer verborrágico de proclamarem, com a mesma voz diabólica de Carvalho, serem o estudo e o debate de ideias tolices irritantes.

A pretensão de expor a "patologia intelectual brasileira" não parece ter assimilado o próprio autor entre "essa gente do mesmo sangue", fazendo-o dizer "de igual para igual, no tom irritado de quem não fala de cima, julgando e condenando com neutra autoridade, mas se sente contaminado e envergonhado pelas culpas dos seus" ${ }^{2}$ ? É possível assumir haver alguma justificativa honrosa em simplesmente pagar o mal com mal? Ou a inten-

${ }^{59}$ CUNHA, ob. cit. p. 175 grifos nossos.

${ }^{60}$ CARVALHO, O imbecil coletivo, ob. cit. p. 37.

${ }^{61}$ Essa referência alquímica como efeito discursivo só surpreende os que não conhecem os primeiros estudos realizados por Carvalho sobre metafísica, esoterismo e alquimia psicológica, e que merecem ainda uma análise minuciosa e específica, sem os rotineiros deboches do passado de astrólogo do autor - o que o tornará menos excêntrico e mais letal quando articulados com sua proposta de uma dialética simbólica (Carvalho, A dialética simbólica).

${ }^{62}$ CARVALHO, O imbecil coletivo, ob. cit. p. 45. 
ção de Carvalho seria a de neutralizar a credibilidade das ideias daqueles contra quem ele se volta pondo-as no mesmo patamar de suas próprias tolices? Não seria mesmo, afinal, a maior das tolices o enquadramento das opiniões rivais como sendo irritantes, se tal enquadramento é feito com a mesma irritabilidade, contaminado pela patologia que pretende curar? Deixemos falar o Schopenhauer da tradução de Carvalho:

Donde provém isso [a possibilidade de se estar com a verdade objetiva sem sua validade pela aprovação dos debatedores e ouvintes]? Da perversidade natural do gênero humano. Se esta não existisse, se no nosso fundo fôssemos honestos, em todo debate tentaríamos fazer a verdade aparecer, sem preocupar-nos com que ela estivesse conforme à opinião que sustentávamos no começo ou com a do outro; isto seria indiferente ou, em todo caso, de importância muito secundária. ${ }^{63}$

A honestidade da verdade é o que conforma a indiferença do filósofo pela vitória em debates. $\mathrm{O}$ próprio Aristóteles havia indicado que a distinção entre boa e má retórica, que se põe em analogia com a distinção, respectivamente, entre a dialética e a erística, situa essa última como sofística, por se tratar de uma escolha (proaíresis) em se utilizar dos argumentos de modo a obter determinado efeito político ${ }^{64}$. Segundo Carvalho, no entanto, só se pode filosofar honestamente ao nível de um discurso que se propõe nunca falar impessoalmente, nem a se dirigir a coletividades abstratas, mas a indivíduos de carne e osso. Só há filosofia, portanto, pela polêmica de igual para igual - e a isso o terceiro prólogo de $O$ imbecil coletivo, anexado à obra como um manual do usuário, pretende nos convencer. Esse manual, composto em tonalidade simbólica, teve por intenção apresentar para seus leitores o valor da erística, que silencia as opiniões rivais, como instrumento de guerra política.

Ao descrever a concepção da trilogia que inaugura sua inserção no debate público, Carvalho explicitou as razões simbólicas que o moveram a escolher, para a capa do primeiro livro da série, as figuras de Behemoth e Leviatã, os monstros bíblicos que, segundo ele, ilustram "forças cómicas desproporcionalmente superiores ao homem, que movem combate uma à outra no cenário do mundo, mas também dentro da alma humana"65. Enquanto a pesada força de Behemoth atua no ventre, a do Leviatã encontra-se na língua, o lugar do flexível poder psíquico da revolta. Para Carvalho, ao abandonar o terreno da luta interior, o ser humano transferiu a contenda monstruosa para os âmbitos da política e da história, de modo que as guerras

\footnotetext{
${ }^{63}$ SCHOPENHAUER, ob. cit., p. 96.

${ }^{64}$ Sobre a distinção entre capacidade e escolha, ver Aristóteles, Retórica, 1355b15-21; sobre a aproximação de retórica e dialética na política, ver Retórica, 1355b35-1356a20. Essas indicações são analisadas por Berti (BERTI, Enrico. As razões de Aristóteles. Tradução Dion Macedo. São Paulo, Loyola, 2002, p. 171-180) no que ele chama uma relação estrutural entre dialética, retórica e filosofia em face da sofística e da política.

${ }^{65}$ CARVALHO, O imbecil coletivo, ob. cit. p. 29.
} 
traduzem a doença espiritual e a cegueira de se pensar capaz de dominar o poder cósmico através da materialidade da razão. Se o simbolismo, tal como Carvalho o explica a partir da tradução que Blake faz da figuração bíblica, indica Behemoth como sendo "o conjunto das forças obedientes a Deus" e Leviatã como sendo "o espírito de negação e rebelião", a constatação de que "ambos são igualmente monstros" situa-os, desde a época do Iluminismo, como representação de duas forças políticas antepostas: "do rígido conservadorismo e da hübris revolucionária", respectivamente; e dada a monstruosidade de suas artimanhas, ao escaparem do controle humano, só podem ser vencidas pela autoridade divina ${ }^{66}$.

A ilustração desses poderes humanos, transmutados em guerra política constante, parece esclarecer o ciclo de vitórias e derrotas que a autonomia individual, marca da mentalidade moderna, materializara em seu anseio democrático de liberdade e igualdade. Essa materialização, ao mesmo tempo psicológica e sociológica, permite a análise das ideologias feita por Carvalho, ao descrevê-las como "sempre limitadas à dimensão horizontal do tempo e do espaço" (Ibidem, p. 30). Como escapar dessa limitação, senão pelo retorno da monstruosidade política ao mais íntimo dos indivíduos? Um lamento que o autor apresenta, de talvez não ter sua obra podido articular, no juízo do seu leitor, o ciclo das lutas terrenas e históricas com a dimensão cósmica e individual da salvação, esclarece na verdade a maneira pela qual Carvalho, ao dirigir-se à consciência individual, pretende transformar a intimidade de seus leitores em campo de batalha político, ao convencê-los do juízo final pela vitória de Behemoth, o monstro da necessidade natural obediente a Deus, sobre a língua da revolta de Leviatã - vitória, contudo, que subjuga ambos à morte, condenados pela autoridade divina, a única capaz de arbitrar o ciclo político entre "direita e esquerda" e de, com isso, subverter a "lei da mútua compensação dos contrários" ${ }^{67}$. Lendo atentamente essa simbologia, parece claro haver o autor se empenhado em traduzir a guerra política, na prerrogativa da vitória de Behemoth sobre Leviatã, como um mandamento divino a seus leitores, cuja aceitação equivale à salvação - física, social, cultural e espiritual.

A inclinação a Behemoth como a um apostolado, presente ao centro da atuação discursiva de Carvalho, não impediu, todavia, que na luta

\footnotetext{
${ }^{66}$ Ibidem, p. 29.

${ }^{67}$ A dinâmica de interação entre polaridades como uma lei cósmica do pensamento foi descrita no estudo sobre dialética simbólica (Carvalho, A dialética simbólica), em que o escritor procurou destacar a diferença de consideração entre a oposição simétrica e estática dos conceitos universais e a dinâmica de complementariedade entre eles no reino dos particulares, a fim de caracterizar sua dialética simbólica a partir de uma noção de analogia referida ao reino intermediário entre os conceitos e as experiências, o das formas imaginais da mitologia e das narrativas bíblicas. Com isso, entende-se por que o autor se valeu dos monstros bíblicos para descrever o paradigma da luta política enfim interiorizado por seus leitores como símbolo de um chamado divino.
} 
política a força de Leviatã pudesse ser usada a seu favor. Não poucas vezes, Carvalho pontuou a necessidade de se utilizar as estratégias políticas dos adversários, uma tática de inversão bastante similar à que Leirner diagnosticou ${ }^{68}$, em referência às práticas dos militares brasileiros. Significa dizer que, contra uma hegemonia cultural e política da esquerda na maioria das instituições públicas do país, assumida como um plano de dominação comunista ${ }^{69}$, pode-se muito bem inverter os papéis das forças monstruosas: a língua da revolta de Leviatã passa a ser instrumentalizada para disseminar a suspeita e a discórdia, a fim de reverter a autoridade política do contrato social pela guerra de todos contra todos. A evocação de Hobbes não é casual, pois a simbólica dos monstros bíblicos nomeia duas de suas principais obras políticas: Leviatã, o poder estatal cuja pacificação da guerra é obtida pela reverência social à autoridade da lei, está constantemente sob a ameaça de guerra civil, originada pelo poder de Behemoth que divide e enfraquece a soberania desde dentro ${ }^{70}$. A vitória de Behemoth, traduzida em mandamento divino por Carvalho, ecoa a simbólica hobbesiana ao pretender subverter a autoridade das instituições pela verborragia erística de uma missão revolucionária: Rocha muito sagazmente percebeu que, para toda uma geração nascida durante os governos de esquerda, a posição de direita em política se mostrou revolucionária. Se nossa argumentação pôde mostrar de que modo a atuação política de Carvalho realiza-se por uma retórica capaz de silenciar os indivíduos diante do mandamento da agitação civil contra o adversário político pintado de inimigo público, o discurso que decorre dessa produção de anti-indivíduos acaba por impedir o debate de ideias em favor da imbecilidade de uma guerra de todos contra todos - sem que o outro lado acreditasse possível ver ruir, tão rapidamente, certa confiança no conhecimento, sob o peso revoltoso da ignorância.

\footnotetext{
${ }^{68}$ LEINER, ob. cit., p. 18.

${ }^{69}$ Esse leitmotiv da atuação intelectual de Carvalho, exposta na primeira de suas obras polêmicas (Carvalho, A nova era e a revolução cultural) e defendida em termos de geopolítica no debate transcrito com o professor russo Dugin (Carvalho, Nova Ordem Mundial), ecoa como dever cristão junto ao seu público católico, que lhe ouve constantemente referir-se à condenação do comunismo pela Igreja. Sua própria maneira de cunhar para a esquerda (referindo-se, no fim, a todos os que não comungam dos valores da extrema-direita) a pecha de comunista foi assumida em larga escala por seus adeptos, entre os quais Flávio Gordon, como se fosse uma autêntica descrição da realidade brasileira: "com efeito, Olavo tinha e continua tendo razão" (GORDON, Flávio. A corrupção da inteligência. Intelectuais e poder no Brasil. Rio de Janeiro, Record, 2018, p. 49). Essa 'razão' ecoa aquilo que Rocha (op. cit., p. 111-112) apontou como conceito-chave da guerra cultural: "o anticomunismo de almanaque de Guerra Fria foi o primeiro passo na ascensão da nova direita".

${ }^{70}$ Sobre a interpretação dos dois símbolos em Hobbes e suas implicações políticas e constitucionais, ver LYNCH, Christian. "Entre o Leviatã e o Beemote: Soberania, constituição e excepcionalidade no debate político dos séculos XVII e XVIII". DADOS - Revista de Ciências Sociais, Rio de Janeiro, vol. 53 (1), p. 55-90, 2010.
} 


\section{Considerações finais}

Em outra das intermináveis notas introdutórias de O imbecil coletivo, Carvalho expôs uma nova leitura de sua obra, agora valendo-se da imagem escolhida para contracapa do livro, pondo-se a assumir a si mesmo e a seus leitores como os porcos da imagem de Albrecht Dürer, condenados "a comer do mesmo cocho e a ouvir o mesmo discurso" do humano doutor ${ }^{71}$. Se é explícita a remissão à imagem de Dürer, pela ironia da passividade suína que só come o que lhe é oferecido pela condição intelectual dos doutores, a referência aos porcos revolucionários de Orwell parece latente: em A Revolução dos bichos, a ironia tinha sido a de transformar os porcos revolucionários em reprodutores da desumanidade humana por eles então combatida - que acabou ainda mais desumana por se tratarem de bichanos como os demais. $\mathrm{O}$ apelo à revolução cultural em Carvalho, a partir do exílio dos anti-indivíduos fundamentado na recusa ao debate de ideias e na visão nostálgica de um passado negado pelo progresso ${ }^{72}$, não se satisfaz com o diagnóstico da situação intelectual brasileira: ele repercute, igualmente, um discurso de porcos - capaz de conduzir os bichanos ao silenciamento da voz adversa, despertando o poder de Behemoth que corrói as bases da soberania democrática, instrumentalizando o poder de Leviatã contra ele mesmo.

Como Schopenhauer indicou, não sendo possível estabelecer previamente o juízo que diz algo real e o que só diz aparência, bem como não se pode ter clareza prévia sobre a intenção dos debatedores, a não ser através da sua análise pela dialética ${ }^{73}$, procuramos esclarecer aqui as intenções e os valores da proposta discursiva de Olavo de Carvalho a partir da análise de sua leitura sobre Aristóteles, para descobrirmos, ao final, que a confusão acerca dos quatro discursos não apresenta necessariamente uma interpretação consistente face aos estudos aristotélicos, mas a forma de Carvalho reunir algumas notas para conferir teor filosófico à sua confecção intelectual: a redução de todo discurso ao jogo de poder, situando a demonstração científica e a poesia como mecanismos de persuasão, cuja finalidade é a

\footnotetext{
${ }^{71}$ CARVALHO, O imbecil coletivo, ob. cit. p. 19.

72 "Trata-se da imaginação distorcida de alguém que, em um meio 'onde os outros veem o rio do tempo fluindo como sempre fluiu', enxerga 'os destroços do paraíso passado à deriva'. O aluno do COF (e, obviamente, seu professor) 'é um exilado do tempo"' (Cunha, op.cit., p. 168). A transcrição, imediatamente anterior, de uma fala de Carvalho em suas aulas é satisfatória para ilustrar a pretensão intelectual que impede o debate e atomiza as consciências: “É preciso criar outras funções, inventar novos meios de atuação; não temos que nos amoldar em nada ao presente estado de coisas. Não devemos tentar fazer algo que seja compreendido pelo presente meio acadêmico, mas fazer coisas que só serão realmente compreendidas por pessoas como nós, que existirão no futuro. Podemos intervir pontualmente no debate atual, para denunciar certas pessoas, mas a preocupação fundamental é criar um outro debate acima deste, que irá se sobrepor ao atual e, pelo seu peso, fará este ceder" (Carvalho apud Cunha, op. cit., p. 167 grifos nossos).

${ }^{73}$ SCHOPENHAUER, op. cit., p. 123.
} 
modificação da consciência do ouvinte/leitor e cujos efeitos acumulam tanto a atomização das opiniões quanto a impossibilidade do exercício dialógico. Ambos os efeitos se constatam a partir da própria atuação de Carvalho, sobretudo naquela atuação de polemista, ao aglutinar para si a impressão de sempre ter razão enquanto despreza o interlocutor inimigo para fazê-lo digno apenas de zombaria, xingamentos e assassinato de reputação. Esse tipo de atuação política alimenta diversos anti-indivíduos, exilados da sociedade atual porque dispostos a integrarem um corpo místico imbuídos de missão intelectual, em larga escala similares à ralé que Arendt identificou no seio dos totalitarismos. A ameaça desse tipo de atuação, portanto, exige diagnósticos e tratamentos eficazes.

Em sua análise sobre o fenômeno político desencadeado por Carvalho, Rocha $^{74}$ indicou os elementos contextuais aos quais se deveria remeter a expressão retórica do ódio, distinta da mais popular discurso de ódio. Procuramos demonstrar que as bases da atuação discursiva de Carvalho, cujos efeitos retóricos concentram-se na performance potencializada pela internet em programas e cursos ${ }^{75}$, deriva da leitura que ele faz de Aristóteles para conferir teor filosófico ao seu reacionarismo e ao estorvo do debate. A raiz intelectual da retórica do ódio é, portanto, a retórica erística ${ }^{76}$. Esse ponto é fundamental para tornar inteligível a articulação entre ação e teoria em Carvalho, permitindo mensurar seu poder de influência que se amplia cada vez que mais se arroga a pretensão intelectual de curar a idiotice ao redor, produzindo consciências aprisionadas numa autoridade que silencia o saber em favor da convicção. Se fosse possível a Aristóteles ler Carvalho, a ironia sutil do Estagirita o faria pontuar, em meio à primorosa erudição do autor brasileiro e à constatação dos seus efeitos públicos, que ele não produziu senão "uma coletividade de pessoas que se reúnem com a finalidade precípua de imbecilizar-se umas às outras - e obtêm nisto um razoável sucesso"77. De certa forma, faria recordar a lição deixada por outro grande sábio: "pelos seus frutos os conhecereis".

\footnotetext{
74 “Uma técnica discursiva que propõe a eliminação (inicialmente) simbólica do outro; favorece o surgimento do analfabetismo ideológico; propicia a irrupção de uma constrangedora idiotia erudita; alimenta um excêntrico anti-intelectualismo com base num excesso mal digerido de referências bibliográficas secundárias; mescla autodidatismo e autoengano; confunde a tarefa do pensamento com a ginasiana "lógica da refutação", reduzindo o diálogo a uma esgrima adolescente de memes e de "lacrações"; e, por fim, transforma a dissonância cognitiva na mola mestra do sistema de crenças Olavo de Carvalho" (Rocha, op. cit., p. 158-159).

${ }^{75}$ A partir do programa de rádio via internet True Outspeak, criado em 2006 (a primeira forma significativa da performance erística de Carvalho), e depois com a criação do canal no Youtube e do Curso Online de Filosofia (COF) em 2009, pode-se mensurar o que chamei neste artigo de atuação política de Carvalho, potencializada depois pelo avanço das mídias e redes sociais, como o Facebook, mas que já estava prefigurada em sua teoria.

${ }^{76}$ Não sendo, contudo, um conceito aristotélico, acredito justificado, em sua atribuição à obra de Carvalho, pelo que entendo como a confluência da prática de uma dialética erística com os recursos persuasivos da retórica.

${ }^{77}$ Essa é a definição de Carvalho para seu conceito do imbecil coletivo.
} 


\section{Referências}

Arendt, Hannah. Origens do totalitarismo. São Paulo, Cia das Letras, 1998.

Aristotele. Organon. Coordinamiento e introduzione generale de Maurizio Migliori. Milano, Bompiani, 2016. Aristóteles.

- Tratados de Lógica I (Órganon). Introducciones, traducciones y notas de Miguel Sanmartín. Madrid, Gredos, 1982.

. Tratados de Lógica II (Órganon). Introducciones, traducciones y notas de

Miguel Sanmartín. Madrid, Gredos, 1988.

. Retórica. Prefácio e introdução de Manuel A. Júnior. Lisboa, INCM, 2006.

. Ética a Nicômaco. Tradução, introdução e notas de Antônio C. Caeiro. São Paulo, Atlas, 2009.

. De Anima. Tradução, introdução e notas de Maria C. G. dos Reis. São Paulo, editora 34, 2012.

Metafísica, vol 1 a 3. Tradução de M. Perine da edição de Reale. São Paulo, Loyola, 2014. 34, 2015.

Poética. Tradução, introdução e notas de Paulo Pinheiro. São Paulo, editora

Berti, Enrico. As razões de Aristóteles. Tradução Dion Macedo. São Paulo, Loyola, 2002.

Butscher, S. Aristotle's Theory of Poetry and Fine Art. London, Macmillan \& Co, 1932.

Carvalho, Olavo. Aristóteles em Nova Perspectiva. São Paulo, É Realizações 1996.

. A filosofia e seu inverso. Campinas: Vide editorial, 2012.

. Os EUAs e a Nova Ordem Mundial. Um debate entre Alexandre Dugin e

Olavo de Carvalho Publicado no Brasil. Campinas, Vide editorial, 2012.

O mínimo que você precisa saber para não ser um idiota. Organização e introdução de Felipe Moura. Rio de Janeiro, Record, 2013.

. A nova era e a revolução cultural. Fritjof Capra \& Antonio Gramsci. Campinas: Vide editorial, 2014 [1ํㅡㄹ. 1994].

[1'ed 2007].

A dialética simbólica. Ensaios reunidos. Campinas, Vide Editorial, 2015

. O imbecil coletivo. Rio de Janeiro, Record, 2019 [1를 1996 ].

. Edmund Husserl. Contra o psicologismo. Campinas, Vide Editorial, 2020.

Cunha, Martins V. A tirania dos especialistas. Desde a revolta das elites do PT até a revolta do subsolo de Olavo de Carvalho. Rio de Janeiro, Record, 2019.

Dilthey, Wilhelm. O surgimento da hermenêutica. Tradução Eduardo Gross. Numen: Revista de estudos e pesquisa da religião, Juiz de Fora, v. 1. n. 1, p. 11-32, 1999 [1 ${ }^{\mathrm{a}}$ ed. 1900].

Diógenes Laércio. Vidas e doutrinas dos Filósofos Ilustres. Tradução e notas de Gama Cury. Brasília, Ed. UNB, 2008 
Duarte, Letícia. "Como o olavismo explica o bolsonarismo". Retrato Narrado, 18 de outubro de 2020. [Link de acesso ao podcast: http://spoti.fi/391wXG0].

Düring, Ingemar. Aristotele. Traduzione italiana di P. Donini. Milão, U. Mursia editore, 1976.

Hussne, Arthur. "Olavismo e bolsonarismo". Revista Rosa, I, março de 2020 [disponível em https://revistarosa.com/1/olavismo-e-bolsonarismo]

Leirner, Piero. O Brasil no espectro de uma guerra híbrida. São Paulo, Alameda, 2020.

Mesquita, Pedro. Introdução geral: As obras completas de Aristóteles. Lisboa, INCM, 2005.

Modrak, Deborah. Aristotle's theory of language and meaning. Cambridge, Cambridge University Press, 2001.

Moraux, Paul. Les listes anciennes de ouvrages d'Aristote. Louvain, Éditions Universitaires, 1951.

Rocha, João C. C. Guerra Cultural e Retórica do ódio. Goiânia, Caminhos, 2020.

Rossetti, Lívio. Introdução à Filosofia Antiga. Tradução de Élcio Viçosa Filho. São Paulo, Paulus, 2006.

Schleiermacher, Friedrich. Hermenêutica. Arte e técnica da interpretação. Tradução de Celso Braida. Petrópolis, Vozes, 2010.

Schopenhauer, Arthur. Como vencer um debate sem precisar ter razão. Dialética Erística. Introdução, comentários e notas de Olavo de Carvalho. São Paulo, Topbooks, 1997.

Endereço do Autor:

Rodovia JK, 3200 - Bloco D - Apt. 401

Bairro Universidade

68903-419 Macapá - AP

dealencar.prof@gmail.com 